\title{
Aproximación genealógica a la población de vagos en Colombia*
}

\section{Genealogical approach to the population of ba in Colombia Abordagem genealógica para a população da ba na Colômbia}

Revista LOGOS CIENCIA \& TECNOLOGÍA ISSN 2145-549X Vol 4. No. 1, Julio - Diciembre, 2012, pp. 12-57

\section{Resumen}

El presente ensayo tiene como propósito reflexionar acerca de las políticas y dinámicas de control social

\section{Fecha de recibido: 11 de abril de 2012}

\section{Fecha de aceptación: 23 de mayo de 2012}

* Este Artículo es producto de los Grupos de Investigación en Filosofía Política Contemporánea de la Universidad Libre de Colombia, reconocido por Colciencias en categoría "C" 2009 y Grupo de Investigación en Derecho Penal, Criminología y Política Criminal Cesar Bkria, Categoría "C" 2010.

** Filósofo egresado de la Universidad Nacional de Colombia, Especialista y Magíster en Filosofía del Derecho y Teoría Jurídica de la Universidad Libre, Magíster en Historia de la Pontificia Universidad Javeriana y Candidato a Doctor en Estudios Políticos y Relaciones Internacionales de la Universidad Externado de Colombia. Director del Centro de Investigaciones de la Facultad de Filosofía de la Universidad Libre y director del Grupo de Investigación en Filosofía Política Contemporánea de la misma Universidad, reconocido por Colciencias en categoría "C" 2009. Docente de la Universidad Libre y Fundación Universitaria Autónoma de Colombia (FUAC). Correo electrónico: eliascastro_filosofia@yahoo.es

*** Abogado, Especialista en Derecho Penal y Probatorio de la Universidad Católica de Colombia. Magíster en Derecho Penal y Ciencias Criminológicas de la Universidad Externado de Colombia, ex Fiscal Especializado e investigador del Grupo de investigación en Derechos Humanos Antonio Nariño, Categoría B, 2010. Correo electrónico: archila29@hotmail.com e inclusión en Colombia, expresadas mediante el ordenamiento jurídico, plasmado en la legislación que contempla lo relacionado con la estructura institucional a nivel nacional, regional y local. El Derecho contribuyó en buena medida a regular las tensiones de inclusión y exclusión social en Colombia, como fue el hecho de conminar a los vagos a trabajar en la construcción de carreteras, caminos y labores agropecuarias en las Colonias Penales.

Palabras clave: Vagos, exclusión social, derecho, legislación, asistencia social, asistencia pública, códigos de policía.

\section{Abstract}

This essay is intended, reflect on the political and social control dynamics and inclusion in Colombia, expressed through the legal system, embodied in legislation requiring do with the institutional structure at the national, regional and local levels. The law largely contributed to tensions regulate social inclusion and exclusion in Colombia, as was the fact admonish bums to work in the construction of highways, roads and agricultural work in the penal colonies.

Key words: Vagos, social exclusion, law, legislation, social welfare, public assistance, police codes. 


\section{Resumo}

Este ensaio pretende, refletir sobre a dinâmica de controle político e social e inclusão na Colômbia, expressa através do sistema legal, consubstanciado na legislação exigindo ver com a estrutura institucional, a nível nacional, regional e local. A lei contribuiu largamente para regular as tensões inclusão e exclusão social na Colômbia, foi o fato de vagabundos admoestar a trabalhar na construção de rodovias, estradas e trabalho agrícola das colônias penais.

Palavras-chave: Vagos, a exclusão social, direito, legislação, assistência social, assistência pública, códigos de polícia.

\section{INTRODUCCIÓN}

La vagancia se circunscribió en un problema social y se manifestó en dos tipos de acciones asistenciales: pública y privada, como lo explica María Himelda Ramírez en su obra De la caridad barroca a la caridad ilustrada ${ }^{1}$. El sentido de asistencia social en Colombia se ajusta a la tradición occidental, donde la pobreza se asocia a fenómenos que la generan, así como sus posibles soluciones. La autora se ha ocupado de señalar el tratamiento dado a la pobreza, en función de la desigualdad de género en la sociedad santafereña durante los siglos XVII y XVIII.

La asistencia a los pobres como un deber cristiano, es una típica herencia medieval, como lo sugiere la investigadora Carmen Alonso López: "Si existe una palabra clave para definir las actitudes teóricas, y gran parte de las prácticas, cara al pobre y la pobreza, esta ha de ser "caridad" [...] el pobre es considerado tanto en los textos evangélicos como en la doctrina de los Padres de la Iglesia y en la de los tratadistas medievales como el puente entre el hombre y Dios, el intermediario privilegiado en el camino de la salvación a quien hace la limosna [...]"2. Dilucidar este concepto es vital, puesto que de allí se derivan

1 RAMÍREZ, María Himelda. De la caridad barroca a la caridad ilustrada. Mujeres, género y pobreza en la sociedad de Santa Fe de Bogotá, siglos XVII y XVIII. Bogotá: Universidad Nacional de Colombia, 2006.

2 LÓPEZ ALONSO, Carmen. La acción social medieval como precedente. Citado por María Himelda Ramírez en: no solo connotaciones sociológicas sino políticas, orientadas a la prestación de ayudas específicas a tipos de población vulnerable.

"Los pobres fueron en general y básicamente clasificados en dos grandes categorías: los pobres deseados y los indeseados. La mayoría de los historiadores admiten que esta clasificación era común en Europa desde el siglo XVI. Uno de los objetivos principales de esa división era la regulación estricta contra la mendicidad en las calles, junto con la idea del confinamiento de los pobres. Los pobres deseados recibirían asistencia de las instituciones religiosas o de los individuos filantrópicos, mientras que los indeseados serían sujetos de control secular y disciplinar"3.

En España fue prolífica la producción legislativa, incorporada en gran parte en la Nueva Granada a partir de la segunda mitad del siglo XVIII dentro de lo que se conoce como "caridad ilustrada", entre las que merecen destacarse las relacionadas con vagos y mendigos, conminados a vivir en hospicios.

La historiografía europea en relación con la pobreza ha sido más prolífica que en América, donde algunos períodos han sido más estudiados que otros -segunda mitad del siglo XVIII- a diferencia de otros donde ha sido menos notorio este tipo de aportes - primera mitad del siglo XIX- donde se ha registrado un vacío historiográfico latente en relación con las políticas adoptadas en distintas administraciones. El siglo XIX se

De la caridad barroca a la caridad ilustrada. Op., cit, pp. 129-130.

3 CASTRO CARVAJAL, Beatriz. Caridad y beneficencia, el tratamiento de la pobreza en Colombia. Bogotá: Universidad Externado de Colombia, p. 70. prolífica la producción legislativa, incorporada en gran parte en la Nueva Granada a partir de la segunda mitad del siglo XVIII dentro de lo que se conoce como "caridad ilustrada", merecen destacarse vagos y mendigos, conminados a vivir en

hospicios. las relacionadas con 
caracteriza por atribuirle una connotación más secular que cristiana al sentido de la beneficencia, en lo relacionado con la satisfacción de las necesidades por parte del Estado, postura que se refleja con mayor claridad en las reformas liberales que marcaron diversas épocas como 1851, 1863 y 1876 que corresponden a la liberación de la esclavitud, Constitución de Rionegro y la difusión del pensamiento liberal radical, respectivamente. Durante los años de hegemonía conservadora el debate es casi inexistente, lo que demuestra una rivalidad no solo partidista sino ideológica en la manera de asumir el sentido de lo social. Estudios recientes sobre la pobreza han establecido la distinción entre caridad y filantropía, ubicando la primera como el tipo de ayuda voluntario ligado a una connotación cristiana, a diferencia de la segunda, asociada a un tipo de ayuda estatal.

Cabe señalar que 1851 es un momento histórico significativo para analizar el auge del pensamiento liberal que se traduce en el librecambismo, el desarrollo de las libertades individuales, pero quizá el mayor esfuerzo de los liberales en este contexto de siglo estuvo orientado a cuestionar las leyes contra la vagancia, que a todas luces resultaba improcedente, frente al ascenso de la tadición liberal.

La historia -según Foucault- no se presenta de manera lineal sino discontinua, o hechos que marcan una ruptura surcados por acontecimientos trascendentales; es así como la aproximación genealógica inicia con la dinastía de los borbones, haciendo énfasis en aspectos significativos como el pensamiento liberal y su oposición frente a estas prácticas gubernamentales que reñían a todas luces con la promulgación de un sujeto que puediera desarrollarse libre y autónomo, en donde el Estado interviniera lo más mínimo en la medida de lo posible. Con todos los saltos temporales que puede presentar una investigación de esta naturaleza, debido a la escasez de fuentes primarias de consulta, el período de cierre lo constituye el Decreto 1863 de noviembre 8 de 1926, por el cual se fija el reglamento de Policía Nacional sobre vagancia y ratería, que es prácticamente la columna vertebral de los códigos departamentales que tuvieron vigencia en lo sucesivo en el territorio nacional. Esta norma contempla lo relacionado con vagos, así como delitos conexos, por ejemplo, los ebrios consuetudinarios, los que se hallaren practicando juegos prohibidos, los reincidentes, rameras, mendigos y los que andan de pueblo en pueblo sin ejercer una industria u oficio que les proporcione honradamente la subsistencia.

En una perspectiva genealógica, Foucault da cuenta del encierro al que ha sido conducido el hombre moderno. El panóptico es considerado como la sofisticación de las técnicas de dominio sobre las subjetividades, los cuerpos y los espacios que habitan. Ahora bien, ¿por qué legitimar un discurso acerca del poder si este en realidad no es nada nuevo? El poder surca todas las esferas de la vida social, pues aunque no se adquiere, se ejerce, se evoca, lo deseamos e incorporamos en todas las esferas del mundo de la vida, aunque no sepamos con certeza cómo opera. Con Foucault podemos hallar una reivindicación de las culturas subalternas o marginadas, los excluidos, y por qué no de los diferentes; además, mediante sus obras podemos analizar una especie de prisma teórico a partir de lo que Foucault denominó gubernamentalidad, o acción estratégica institucional orientada a la atención de los menesterosos, lo que implica previamente la concepción del otro, que requiere de la intervención estatal para convertirlo en sujeto productivo.

Una vez presentada en términos generales la caracterización del problema y la intencionalidad manifiesta, es válido reflexionar acerca de los dispositivos donde se plasmaron estas prácticas: ¿cómo fueron considerados los vagos en relación con las políticas gubernamentales y por la sociedad en general? ¿cuál fue su concurso como fuerza laboral?, ¿en qué medida se alternaron los trabajos forzados con la reclusión en cárceles y colonias penales?, ¿cómo se fue formando gradualmente la rehabilitación de la conducta?, ¿bajo qué presupuestos se fundaron los núcleos poblacionales con vagos deportados?, ¿qué importancia representa el pensamiento liberal como oposición frente a las leyes de vagancia?, y finalmente, ¿cuáles son los usos coloniales y republicanos del término "vagancia"?

Estas serán las preguntas orientadoras frente a las que girará la discusión en lo sucesivo. Las dinámicas gubernamentales frente a los vagos se encuentran 
relacionadas, más que con una concepción frente al ocio, el sentido del trabajo como dignificación de lo humano, que lo aparta de las costumbres insanas y poco edificantes que no contribuyen a forjar la idea de buen ciudadano.

De conformidad con lo anterior, la tesis a sustentar es la siguiente: el derecho constituye en esencia un ejercicio pragmático de gubernamentalidad frente a los vagos en Colombia. De otra parte, el lugar privilegiado para ejercer en sentido fáctico estos dispositivos de seguridad, fueron las cárceles, las colonias penitenciarias y las obras públicas institucionales, además de las expresiones jurídicas plasmadas en ordenanzas y normas de carácter regional y local, y Códigos de Policía, entre otras disposiciones.

En aras de un rigor metodológico, se presenta la exposición temática de la siguiente manera: la primera parte, denominada Horizontes teóricos, se divide en dos partes: la primera denominada Beneficencia, caridad y moralización, hace una caracterización general del problema en donde se contextualiza el tipo de población, incorporando los conceptos de caridad y beneficencia en dos tradiciones distintas: pública y privada, donde los vagos se circunscriben a un problema más de tipo social; la segunda Gubernamentalidad como técnica de gobierno, analiza las expresiones biopolíticas y de poder en función de lo estatal, para dar cuenta de cómo operan estas relaciones de poder en función de las técnicas de gobierno.

La segunda parte, Vagos: el dilema social y la exclusión, se ocupa de reflexionar acerca de problema que representa para el Estado una población que se mantuvo al margen de toda acción productiva. Estas prácticas gubernamentales como lo expresa Foucault, tienen como expresión básica la población, en esa medida las estrategias de poder se visibilizan mediante acciones puntuales, presentadas en diversos contextos como asistencia pública e inclusión social, se asumen como políticas o prácticas administrativas dirigidas a corregir lo no constructor de identidad. Así aparecen las cárceles y las colonias penitenciarias, como expresiones lógico-racionales de la gubernamentalidad, previa a una concepción que se tiene del otro que para este caso pueden operar bajo la relación dual productivo/improductivo, en la que suele clasificarse la población de vagos.

Para dar cuenta de lo expresado con antelación, se procedió a hacer una revisión exhaustiva de la literatura existente escrita por especialistas, evolución histórica de las leyes regionales y nacionales, fuente primaria en los fondos documentales de la Sección República existentes en el Archivo General de la Nación (AGN) y Ordenanzas, de donde fueron tomados algunos estudios significativamente notorios, que sin tener la pretensión de ser analizados como estudios de caso, son comentados la mayoría de ellos y extractados los hechos más significativos.

\section{HORIZONTES TEÓRICOS}

\subsection{Beneficencia, caridad y moralización}

Conceptos como beneficencia, caridad e iniciativas de moralización, son desarrollados por Hayley Froysland en un informe publicado en la revista Memoria y sociedad4. Señala la autora cómo fueron surgiendo gradualmente instituciones caritativas a instancias del Estado, como una forma de contribuir a la erradicación de necesidades básicas, lo que se asoció a la ineficiencia estatal para solucionar problemas sociales. Las iniciativas de caridad reflejadas hacia los más desfavorecidos en Colombia, contri-

FROYSLAND, Hayley. Caridad, asistencia pública y moralización: El mantenimiento de un orden social paternalista y jerárquico en Colombia, 1850-1940. Publicado en: Memoria y Sociedad. Revista del Departamento de Historia y Geografía. Bogotá: Universidad Javeriana, Vol. 2 No. 4, noviembre de 1977. La autora era candidata en ese entonces al doctorado en el departamento de historia, University of Virginia, en 1997 y se encontraba desarrollando esta investigación en Colombia. 
buyeron a la consolidación de una estructura paternalista. En este proceso de modernización y ante las necesidades apremiantes, las élites criollas tuvieron un concepto deplorable de la muchedumbre anónima, las que no tardaron en ser calificadas de irracionales, inmorales y turbulentas.

"Un enfoque central de este estudio -dice la autora- será la ideología y los códigos morales que guiaron al Estado y a las élites en sus políticas de caridad y asistencia pública, así como los esfuerzos de moralización en su percepción de los pobres"5.

Cuando el Estado asumió el control de las necesidades -justo en un país donde el catolicismo tuvo un fuerte arraigo- el nivel de participación de la esfera privada representado en la iglesia y particulares no fue fácilmente transferible, pues estaba presente el dilema de qué hacer con esa población de menesterosos. En este concierto, los motivos humanitarios se vieron reflejados en temas como "la reforma moral, la eugenesia, la salud pública, la higiene, el embellecimiento de ciudades, la educación, la asistencia pública y la producción económica"6.

Cuando el Estado colombiano tomó la iniciativa en 1907 de asumir la responsabilidad del bienestar social, bajo la tutela de instituciones de beneficencia y de caridad -aun cuando existían unas relaciones patrón-cliente, asimiladas a la institución eclesiástica (entiéndase jerárquica)- es válido preguntarse, ¿qué tensiones suscitaron estos dos modelos de asistencia social? Froysland señala que la mejor manera consistió en apelar a experiencias similares y una copiosa literatura relacionada con modelos tomados de Europa y los Estados Unidos, sustentados en teorías humanistas y de control social. Al hacer el balance bibliográfico, se encuentra con que existe una escasa documentación en relación con América Latina y aún más para el caso colombiano. Los sistemas de previsión y seguridad que han sido objeto de estudio, (relativamente pocos) se derivan del ámbito legislativo, situación que deja de lado factores tan importantes como culturales, sociales e ideoló-

\footnotetext{
$5 \quad$ Ibíd, p. 153

6 Ídem.
}

gicos. Los más beneficiados con esta medida, según la relación patrón-cliente, fueron los empleados oficiales, lo que condujo a una situación de exclusión, por lo que no fueron tenidos en cuenta "los trabajadores pobres no organizados, los trabajadores rurales, los del sector informal, ni mucho menos los 'marginales'7.

En países como Argentina, Brasil, Chile o México, donde tuvieron un mayor arraigo los modelos autoritarios y revolucionarios, el Estado respondió en la primera mitad del siglo XX de manera más benéfica a problemas agrarios y laborales. Para el caso colombiano el asunto es bien distinto, pues al no existir una separación entre Iglesia y Estado, se fusionan $y$ delegan las funciones asistenciales y de caridad en la institución eclesiástica. Esto explica en alguna medida la presencia de comunidades en Colombia que asumieron estas responsabilidades altruistas de prestar su concurso en hospitales, lazaretos, manicomios, cárceles y orfanatos, entre otros.

Las sociedades de caridad en Colombia tuvieron un notorio desarrollo en Colombia durante los siglos XVIII y XIX. El 6 de julio de 1864, a instancias del presidente Carlos Holguín y su ministro de gobierno, José Domingo Ospina y un colectivo de 39 artesanos, se fundó la "sociedad de caridad", que tuvo como sustento la confraternidad humana, en donde se fijaron como objetivos, "el trabajo en todas sus manifestaciones, la honradez en todos los actos de la vida y la fraternidad, unida a la verdadera caridad en todas las circunstancias"8. El sentido de beneficencia involucró a los estratos más altos de la población, lo que se tradujo en una forma de adquirir

\section{Ibíd, p. 155.}

8 MUÑOZ, Antino. Apuntes sobre un centenario. Sociedad de la caridad, 1964, p. 7. Al interior de la sociedad fueron creadas varias comisiones, entre ellas la hospitalaria, en donde los asociados tenían la obligación de auxiliar a los enfermos y prestar su concurso en momentos de dolor. Además de la ayuda entre los asociados, los miembros de la sociedad carismática sustentaron sus servicios en tres virtudes teologales: la fe, que ayuda a salvar el hombre fiel a las enseñanzas de Jesús; la esperanza, como la motivación de esperar recompensa cuando el hombre asume su papel como cristiano; y la caridad, que en el crecimiento espiritual abreva en las fuentes de la bondad y el amor. 
poder y prestigio social mediante contribuciones económicas y trabajo voluntario.

Inglaterra representa un caso atípico: en 1601 había entrado en vigencia la poor law, función que le encomendaba al Estado la misión de cuidar de los menesterosos, a diferencia de los países colonizados por España donde la tradición católica tuvo un papel destacado, la caridad fue derivada de un proyecto teológico y cristiano.

"Por su carácter espiritual, la caridad y asistencia a los pobres quedó en manos privadas y de la iglesia. Aunque agencias públicas patrocinaron hospitales y otras instituciones de caridad, la responsabilidad principal por el manejo financiero y administrativo permaneció en confraternidades, conventos, la iglesia y benefactores pudientes".

Con los cambios introducidos en la naciente república, los servicios de asistencia no sufrieron modificación alguna; las reformas radicales de mediados del siglo mediante la confiscación de bienes a la iglesia y demás órdenes religiosas, crearon cierto clima de inseguridad ante la pérdida de recursos; posteriormente, una nueva etapa de renovación tuvo vigencia cuando el control fue asumido por los gobiernos conservadores. Las élites que vivieron el proceso de transición del siglo XIX al XX, todavía contaban con una marcada influencia católica, aunque no estaba exenta la intención de solucionar los problemas que acarreaba la pobreza, apelando a argumentos de orden económico y político. "La caridad -señala Froisland- también servía como un símbolo de su estatus. Su mundo era jerárquico y paternalista. Influidas por la ideología positivista, las élites percibieron la estratificación social como natural e inherente ${ }^{110}$. No es gratuito entonces con-

FROISLAND, Hayley. Caridad, asistencia pública y moralización: El mantenimiento de un orden social paternalista y jerárquico en Colombia, 1850-1940. Op., cit, p. 155.

10 Para resaltar esta tendencia, basta señalar algunos ejemplos de instituciones que aún subsisten y reflejan esta idea moralizante, lideradas en su mayoría por mujeres: el Amparo de niños, (fundada por María Michelsen de López), los hogares denominados Gotas de leche, la Sociedad Protectora de Gamines, la Asociación de Hijas de María Inmaculada y la Casa Protectora de Niñas, entre siderar que personas de cierta condición social se dieran a la tarea de fundar instituciones caritativas y programas de Acción Social Católica, que sirvieron como mediadoras entre el Estado y la sociedad.

Las políticas de salubridad vigentes durante el siglo XVIII, centraron sus reflexiones en el cuidado de la infancia, estadísticas de natalidad y mortalidad. La administración de la vida a través de la medicalización hizo posible la adopción de medidas proteccionistas orientadas al cuidado de la salud y prácticas higiénicas. Nunca antes la población infantil había sido objeto de tantas reflexiones y acciones encaminadas a su defensa. Otra de las preocupaciones de las políticas de salubridad fue la promoción del sentido de la higiene, y el modus operandi de la medicina como instancia de control social. Las instituciones que ejercen control sobre hospicios, manicomios o lazaretos, "tienen la posibilidad no sólo de vigilar sino también de construir un saber sobre aquellos a quienes vigila"11. La concepción de salud pública, como higiene social, se ubica hacia las últimas décadas del siglo XIX; ligada a la idea de salud, aparece el hospital, como lugar de prolongación de

otras. "Las iniciativas de caridad reflejadas hacia los más desfavorecidos en Colombia -dice la historiadora- posiblemente sirvieron para reforzar una sociedad tradicionalmente jerárquica y paternalista en un contexto de modernización". FROISLAND, Hayley. Caridad, asistencia pública y moralización. Op., cit, p. 154. La asistencia pública puede verse además en: Formas asistenciales y de beneficencia en Santa Fe: Hospitales, expósitos y hospicios en la Sociedad de Santa Fé Colonial. Julián Vargas Lesmes (Compilador). Bogotá: CINEP, 1990.

11 FOUCAULT, Michel. La verdad y las formas jurídicas. Barcelona: Editorial Gedisa, p. 100. 
la Junta Central de

Higiene creada en 1887 ,

de igual manera en

cada departamento las

de Higiene que tuvieron

la responsabilidad

de organizar la

salud pública. La

Junta General de

Cundinamarca

estableció una

tipificación en 1888

para los indigentes,

entre los que incluyó
Juntas Departamentales

la existencia, una concepción que rompe con

la anterior tradición, donde aquel fue asociado más a la idea del "bien morir" en términos cristianos, rodeado con los de sus afectos, en paz, pero sobre todo en su lecho; de ahí que fuera considerada poco digna la muerte súbita o de repente, que no daba lugar a la expiación de culpas y el arrepentimiento.

"Es precisamente en este contexto -señala el his-

toriador Carlos Noguera- donde aparece la "salud pública" como concepto nuevo que se diferencia claramente de la concepción anterior. Al respecto Schwartz y Lopes plantean que en los siglos anteriores, las propias instituciones (hospitales, asilos y otros) y las estrategias médicas reflejan una preocupación sobre la muerte y la enfermedad. Los hospitales del Brasil colonial, por ejemplo, muestran en su disposición arquitectónica y en su gestión, marcada por el culto religioso, el propósito de propiciar una muerte tranquila"12.

La higiene como dispositivo de poder está relacionada con el manejo de los discursos y prácticas sociales hacia la población más desfavorecida, en donde se enfatiza el sentido de salubridad ${ }^{13}$. Una de las

$12 \quad$ NOGUERA, Carlos Ernesto. Medicina y política. Discurso médico y prácticas higiénicas durante la primera mitad del siglo XX en Colombia. Medellín: Fondo Editorial Universidad EAFIT, 2003, p. 35.

13 "En tanto dispositivo de poder, la higiene no puede adscribirse a ningún partido político o corriente ideológica en particular. La puesta en marcha del dispositivo higiénico tuvo que ver con acontecimientos de diversos órdenes. De una parte, en el orden del saber, el lugar cada vez más importante que desde la segunda mitad del siglo XX ocupa la higiene dentro de las reflexiones sobre la ciudad y la sociedad en general; de otra parte, en el terreno de las prácticas sociales, las diversas medidas higiénicas que comienzan a adoptarse, desde la última década del expresiones más acertadas para señalar la relación medicina-política, es la presentada por el investigador Carlos Noguera, al plasmar en la expresión medicalización de la política y politización de la medicina, las contingencias presentadas alrededor de estos discursos; la pretensión del autor consiste en "mirar cómo el saber médico se articuló con mecanismos de poder para conformar una estrategia que Michel Foucault ha denominado biopolítica; qué efectos prácticos produjo, cómo influyó en el pensamiento político, en la población -al menos en un sector específico de ella- $y$ en individuos concretos" ${ }^{14}$.

La medicina se construyó con base en referentes disciplinares como la biología, y esta a su vez en elementos que permitieron la adopción de políticas cuyos destinatarios eran los ciudadanos. La higiene hizo visible los focos de infección, la insalubridad, justificando de paso la intervención y control social sobre estos. Algunas de las instancias donde se hicieron visibles estas preocupaciones fueron los relacionados con prácticas eugenésicas, el control y vigilancia a los obreros, el miedo a la protesta social, la lucha antialcohólica, la degeneración racial, la lucha antivenérea, la caza de prostitutas y la aparición de manuales de higienes para civilizar el pueblo.

Enmarcados en esta lógica capitalista, las élites concibieron la raza como el degeneramiento paulatino, situación que debería ser mejorada según valoraciones de los movimientos eugenésicos, los asentamientos obreros como focos de insalubridad, la protesta social -metafóricamente- como un vacilo propenso al contagio, la cacería de prostitutas asociada a la depravación moral y las sanas costumbres, el alcoholismo como un "tósigo maldito" hereditario, asociado a la degradación racial, que a su paso propendería a reorientar hábitos ancestrales como el consumo de la chicha, y los manuales de higiene o instrucción escolar, como la imagen arquetípica de

siglo $\mathrm{XIX}$, en relación con las mejoras públicas y ornato de las ciudades, el saneamiento del espacio urbano (habitaciones, calles, acueducto, alcantarillado) y la higiene personal (baño diario, aseo, ropa, alimentación, etc." Ibíd, p. 124.

14 Ibíd, p. 41 
una sociedad que guiaría a los niños por el sendero de la virtud y el bien obrar.

El desarrollo de las políticas de salubridad se encuentra relacionado con la creación de organismos nacionales y regionales, entre las que se destacan la Junta Central de Higiene creada en 1887, de igual manera en cada departamento las Juntas Departamentales de Higiene que tuvieron la responsabilidad de organizar la salud pública ${ }^{15}$. La Junta General de Cundinamarca estableció una tipificación en 1888 para los indigentes, entre los que incluyó

"a los ciegos, cojos, mancos o tullidos; a los individuos cabeza de familia que sufran alguna enfermedad crónica que los imposibilite en absoluto para trabajar; a las viudas con hijos que no puedan buscar su subsistencia por no poder trabajar; $y$ los huérfanos de padre y madre, menores de diez años"16.

Cabe señalar que esta tipificación no distingue explícitamente la población de indigentes y mendigos, situación que va a permanecer sin cambios significativos hasta 1917, cuando la Junta General de Beneficencia fue más explícita con el fin de determinar el tipo de ayuda que debían recibir y el establecimiento donde deberían ser enviados.

15 Posteriormente, en 1918 la Junta Central de Higiene se convierte en la Dirección Nacional de Higiene. "En 1924 fue creado el Ministerio de Instrucción y Salubridad Pública. La sección salud fue dividida en dos: higiene y asistencia pública. La división de higiene tenía la responsabilidad de controlar la infraestructura urbana -abastecimiento de agua, alcantarillado y basuras- y las epidemias, mantener actualizadas las estadísticas y llevar a cabo campañas de vacunación. La división de asistencia pública tenía la responsabilidad de administrar las instituciones como hospitales, asilos y orfanatos". CASTRO CARVAJAL, Beatriz. Caridad y beneficencia, el tratamiento de la pobreza en Colombia. Op., cit, p. 39.

16 Ordenanza No 12 de 1888. Compilación de Leyes y Ordenanzas de la Beneficencia y Asistencia Social de Cundinamarca. 1860-1942. Bogotá, 1942. Citado por Beatriz Castro en: Caridad y beneficencia, el tratamiento de la pobreza en Colombia. Op., cit, p. 78.

\subsection{La gubernamentalidad como técnica de gobierno}

Creo que, desde el siglo XIX, la filosofía no ha dejado de acercarse a esa pregunta:

"¿Qué ocurre hoy, qué somos nosotros, acaso no somos nada más que lo que ocurre?". El interrogante de la filosofía se refiere a ese presente que somos nosotros mismos.

Por eso la filosofía es hoy enteramente política y totalmente 'historiadora'. Es la política inmanente a la historia, la Historia indispensable para la política".

Michel Foucault*

En un seminario impartido en marzo 17 de 1976, Foucault incorpora asuntos como biopoder y política, y centra sus preocupaciones en las tecnologías de seguridad ejercidas a partir del siglo XVIII cuando son más visibles los dispositivos sobre los sujetos, pero a partir de 1978, desplaza la discusión del poder hacia actividades propias de los gobiernos, para finalmente desarrollar con mayor propiedad el tema de la gubernamentalidad.

El término gubernamentalidad ${ }^{17}$ (distinto a gobernanza) expuesto por Foucault a lo largo de varias de sus obras, y más exactamente a partir de los cursos impartidos por los años de 1978 y 1979 en el College de France, lo acuña para establecer la distinción existente entre la subjetivación y formas de subjetivación. La gubernamentalidad se constituye en dispositivos técnicos de control extensivo no solo a los sujetos sino a la población en general. Bajo esta nueva mirada, el poder no es impuesto de manera vertical desde una visión hegemónica estatal a la manera marxista, sino descentrado a partir de una multiciplicidad de instituciones (familia, escuela, trabajo, religión, orden militar) en donde cada una de estas instituciones tiene su propia visión de los sujetos y a partir de un ámbito particular, ejercen funciones sobre aquellos.

FOUCAULT, Michel. Gubernamentalidad. México: Paidós, 1999. 
Las prácticas gubernamentales tienen como expresión básica la población, y en esa medida las estrategias de poder se visibilizan mediante acciones

Advierte Foucault, cómo la sociedad burguesa y más exactamente con el desarrollo del capitalismo surgen "aparatos de encierro", que buscan corregir las desviaciones sociales. puntuales en diversos contextos como caridad, asistencia pública e inclusión social, presentadas como políticas públicas o prácticas administrativas dirigidas a los grupos poblacionales. Así pues, las cárceles, manicomios y lazaretos, aparecen como expresiones lógico-racionales de la gubernamentalidad, previa a una concepción que se tiene del otro que para este caso pueden operar bajo la relación dual productivo/improductivo, sano/insano, locura/razón, en las que puede clasificarse la población de vagos.

La gubernamentalidad como acción estratégica institucional, orientada a la atención de los menesterosos, implica previamente la concepción del otro como incluido/excluido, objeto de atención estatal ${ }^{18}$. Los saberes médico científicos, así como la estructura racional burocrática orientada a establecer las regulaciones jurídicas, incorporan una visión del otro a ser domesticado y corregido en sus desafueros.

Sorprende la agudeza de un pensador como Foucault para detectar problemas donde pocos filósofos se atreverían a advertirlos, como lo expuso en una serie de conferencias presentadas en la Universidad de Río de Janeiro en 1978, obra que intituló La verdad y las formas jurídicas, las que se convertirían luego en los borradores de vigilar y castigar ${ }^{19}$. Advierte Foucault, cómo la sociedad burguesa y más

18 Un estudio de caso relacionado con el caso colombiano y en especial con la calle del cartucho, puede verse en: ROBLEDO GÓMEZ, Ángela María y RODRÍGUEZ SANTANA, Patricia. Emergencia del sujeto excluido. Aproximación genealógica a la no-ciudad en Bogotá. Bogotá: Editorial Pontificia Universidad Javeriana, 2008.

19 FOUCAULT, Michel. La verdad y las formas jurídicas. Barcelona: Editorial Gedisa, 2000. exactamente con el desarrollo del capitalismo surgen "aparatos de encierro", que buscan corregir las desviaciones sociales. Como una especie de ortopedia social, el capitalismo y su vocación orientada a la producción de bienes materiales, procura corregir y controlar a los individuos mediante discursos que se erigen con pretensiones de verdad.

Como puede derivarse mediante el estudio de sus obras, el pensamiento de Foucault se encuentra surcado por reflexiones no solo de tipo filosófico, sino sociológico e histórico, o para decirlo en otras palabras, es un entramado de discursos bajo los que pretende dar cuenta de ciertas preocupaciones que sus antecesores consideraban como reflexiones propias de otras disciplinas del conocimiento. Tal vez por esta postura, muchos han creído ver en él más que un filósofo, a un historiador, como alguna vez lo puso en evidencia Miguel Morey en una de sus clásicas conversaciones, a lo que Foucault respondió:

"Con la ingenuidad formal de una fábula para niños, le diré que la filosofía lleva mucho tiempo haciéndose esta pregunta: '¿En este mundo en el que todo caduca, ¿qué es lo que no pasa? ¿Qué somos, nosotros los mortales, con relación a lo que no pasa?'. Creo que, desde el siglo XIX, la filosofía no ha dejado de acercarse a esa pregunta: '¿Qué ocurre hoy, qué somos nosotros, acaso no somos nada más que lo que ocurre?'. El interrogante de la filosofía se refiere a ese presente que somos nosotros mismos. Por eso, la filosofía es hoy enteramente política y totalmente 'historiadora'. Es la política inmanente a la historia, la Historia indispensable para la política"20.

En relación con la primera conferencia que hace parte del libro La verdad y las formas jurídicas, la hipótesis de lectura sugerida como esquema de interpretación, consiste en ¿cómo plantear un modelo de reelaboración teórica que permita la reconstrucción del sujeto? Ahora bien, ¿de dónde deviene la necesidad de su reconstrucción? Fou-

20 FOUCAULT, Michel. No al sexo rey. Entrevista por Bernard Henry-Levy, en: Un diálogo sobre el poder y otras conversaciones. Selección e introducción de Miguel Morey. Madrid: Alianza Editorial, 2004, p. 169. 
cault encuentra que usualmente en la tradición marxista universitaria y en Francia más exactamente, se parte del presupuesto de que este no es más que el depositario de todas unas condiciones económicas y sociales que se incorporan en el individuo. Así, Foucault tuvo el mérito de colocarlo en un nivel básico ontológico, consustancial al presente y a la realidad de lo cotidiano y sustentado además en el ejercicio de un poder microcósmico, para desde allí desentrañar los dispositivos en que se asienta ${ }^{21}$.

Así como cada época tiene un modelo de interpretación teórica de los sujetos que se expresan en categorías de verdad, la pretensión de Foucault consiste en demostrar cómo en el siglo XIX, el sujeto como individualidad surge como consecuencia de unos mecanismos de control y vigilancia. Este trabajo de interpretación teórica implica necesariamente reconstruir la idea de sujeto, situación que no es ajena a la reconstrucción de la idea de verdad. Es bien sabida la postura distante que toma en relación con las ciencias humanas, las que se han empeñado en creer que el hombre y todo lo concerniente a su naturaleza constituye el objeto central de sus reflexiones, cuando en realidad es algo reciente. Quizá por ello, el mayor crédito para una filosofía que se ha ocupado del sujeto es el psicoanálisis, tradición que en el pensamiento occidental hizo carrera con Descartes ${ }^{22}$.

$21 \quad$ FOUCAULT, Michel. La verdad y las formas jurídicas. Primera conferencia. Op., cit, p. 69.

22 La réplica de Foucault a Descartes es manifiesta en el sentido de que el filósofo racionalista consideró como única vía, acceder a la verdad de modo positivo; es decir, la certeza científica de la verdad se encuentra por fuera del sujeto. "Me parece que la filosofía moderna -expresa Foucault- por razones que intenté identificar en lo que llamé, un poco en forma burlesca aunque no sea gracioso, el momento cartesiano", es la responsable en alguna medida de la desaparición de la inquietud de sí, al privilegiar el gnothi seauton (conocimiento de sí) y descalificar la epimeleia heautou (preocupación y ocupación de sí)". En síntesis, ¿cuál fue el resultado de todo esto? La objetivación de la verdad por parte del sujeto. Sumado a esto, encontramos la introducción de la idea de Dios, como forma de acceder a la verdad, lo que se considera como un principio de razón suficiente para hallar la certeza. FOUCAULT, Michel. Hermenéutica del sujeto. Barcelona: Editorial Altamira, 1986.
Reconstruir esta idea de sujeto, implica necesariamente reconstruir la relación sujeto-objeto, problema al que puede reducirse la Teoría del conocimiento. Si bien, estas tradiciones gozaron de una fuerte influencia en dos autores representativos, como Descartes y Kant (este último quizá su mayor teórico). En Foucault es clara la intención de desteologizar la naturaleza humana, como refleja el siguiente pasaje: "¿Cuándo cesaremos de ser oscurecidos por todas esas sombras de Dios?, ¿Cuándo conseguiremos desdivinizar completamente la naturaleza?"23 y de paso, la relación sujetoobjeto; solo así podemos hablar de una nueva teoría del conocimiento que asegure una relación entre ese deseo de saber, el instinto, integrado a unos saberes que se expresan en términos de verdad, incorporado a unos sujetos históricos en los que se encarna la idea de dominación y lucha de poderes.

\begin{abstract}
"Ahora bien -señala Foucault- si el genealogista se toma la molestia de escuchar la historia, más bien que añadir fe a la metafísica, ¿qué descubre? Que detrás de las cosas hay 'otra cosa bien distinta'; no su secreto esencial y sin fecha, sino el secreto de que no tienen esencia, o de que su esencia fue construida pieza a pieza a partir de figuras extrañas a ella"24.
\end{abstract}

En los capítulos 2 y 5 de Historia de la sexualidad denominados "Método" y el "Derecho de muerte y poder sobre la vida", señala Foucault cómo deviene en los sujetos la idea del poder, para finalmente enquistarse en la corporeidad de los mismos, hasta hacer de ellos instrumentos funcionales que gobiernan todos los espacios de su vida social.

\footnotetext{
lbíd, p. 25.

24 FOUCAULT, Michel. Nietzsche, la genealogía, la historia. Valencia, España: Pretextos. 2004, p. 18.
} 
Es preciso señalar cómo este pensador intenta recoger tres momentos clave que es preciso aclarar. En primer lugar, antes de sentar alguna posición acerca de la relación de un tipo de saber acerca del sexo, en términos de poder, Foucault va gestando la idea de que el poder es algo omnipresente, no es una institución en sentido estricto pero se encuentra en todas partes; de ahí sus acotaciones cuando expresa que no es algo que se adquiera, o se encuentre en una posición de exterioridad en relación con otros, la direccionalidad que toma, la intencionalidad del mismo o la resistencia que pudiere presentar. Un segundo momento que intenta recoger la lectura de estos textos, y tal vez la central de este discurso, está relacionada con la idea del poder encarnado en los sujetos. Para ello Foucault apela a una dualidad presente en la historia: derecho de vida y muerte. La historia está llena de estos ejemplos clásicos en donde el soberano al disponer de la vida de los súbditos, tenía la capacidad de dar vida o muerte. El problema en sí no está en tomar una opción u otra, sino en el hecho mismo de administrar o gerenciar la existencia con propósitos muy claros, hasta hacer de ellos una biopolítica social. Finalmente, un tercer momento intenta recoger la administración de la vida, en función de la teorización del sexo, no definido a partir de lo genital, sino como abstracción que penetra todas las esferas de la vida cotidiana, donde el poder no está ausente de esta elaboración ${ }^{25}$.

Foucault es uno de los iniciadores de la tradición filosófica e historiográfica, donde empiezan a ser objeto de estudio temas como los vagos, la locura, los lazarinos, la sexualidad, el castigo, la disciplinización del cuerpo, la sociedad reglada y panoptizada, entre otros. Su gran preocupación se centra en mostrar cómo se consolidan estos estudios en función del criterio de "verdad", en lo tocante a las ciencias humanas, del mismo modo que se empeña en mostrar el contexto en el que surgieron como objeto de reflexión.

"Podemos decir esquemáticamente - señala Foucault- que la pregunta tradicional de la filosofía

FOUCAULT, Michel. Historia de la sexualidad. México: Siglo XXI Editores, 1986 política podría ser formulada en los siguientes términos: ¿Cómo puede el discurso de la verdad, o la filosofía entendida como el discurso por excelencia de verdad, fijar los límites del derecho del poder? En lugar de esta pregunta tradicional, noble y filosófica, quisiera hacer otra, que viene de abajo y es mucho más concreta. De hecho, mi problema es establecer qué reglas de derecho hacen funcionar las relaciones de poder para producir discursos de verdad, qué tipo de poder es susceptible de producir discursos de verdad que están en una sociedad como la nuestra, dotados de efectos tan poderosos" 26 .

Tan pronto se inaugura esta nueva preocupación investigativa, aparecen una cantidad de estudios inscritos en este marco de interpretación genealógica. Sus obras muestran que estas experiencias, prácticas y discursos sobre el enfermo, el loco, la sexualidad, son inventos recientes que han surgido a partir de las relaciones establecidas entre el saber y el poder. Es además Foucault uno de los críticos más mordaces de la sociedad capitalista, la misma que se preció de encarnar unos valores y conductas asumidas como normales.

Si existe una obra de Foucault que se ocupe de reflexionar sobre la historia, es la denominada Nietzsche, la genealogía, la historia, en donde profundiza algunas reflexiones señaladas en obras anteriores. Justamente una de sus consideraciones -quizá una manera de hacerle justicia a Nietzsche- es la siguiente:

"La genealogía es gris, meticulosa y pacientemente documental. Trabaja con pergaminos enrollados, borrosos, varias veces reescritos. Paul Ree se equi-

$26 \quad$ FOUCAULT, Michael. Poder, Derecho, verdad, en: Poder vs. Democracia. FICA, Fundación para la Investigación y la Cultura. Bogotá, 2004, p. 14. En torno al concepto de verdad, Foucault hace las siguientes apreciaciones: "Por otra parte, la misma cuestión de la verdad, el derecho que se otorga de rechazar el error o de oponerse a la apariencia, la manera en la que sucesivamente fue accesible a los sabios, retirada luego a un mundo fuera del alcance en el que jugó a la vez el papel de consuelo y de imperativo, rechazada finalmente como idea inútil, superflua, en todas partes rebatida, ¿no es todo eso una historia, la historia de un error llamado verdad?". FOUCAULT, Michel. Nietzsche, la genealogía, la historia. Op., cit, p. 22. 
voca, como los ingleses, al describir génesis lineales al ordenar, por ejemplo, solo en función de lo útil, toda la historia de la moral: como si las palabras hubiesen guardado su sentido, los deseos su dirección, las ideas su lógica; como si este mundo de cosas dichas y queridas no hubiese conocido invasiones, luchas, rapiñas, disfraces, astucias"27.

El método genealógico propuesto por Foucault, rescata la necesidad de reflexionar acerca de lo que para la historia no ha sido objeto de estudio, como "los sentimientos, el amor, la conciencia, los instintos; captar su retorno, no para trazar la curva lenta de una evolución, sino para reconocer las diferentes escenas en las que han representado distintos papeles; definir incluso el punto de su ausencia, el momento en el que no han sucedido"28. En este orden de ideas, Foucault, como lector ávido de Nietzsche, encuentra uno de los soportes genealógicos más importantes para reflexionar acerca del papel que han emprendido las ciencias, consolidadas de manera arrogante bajo la influencia del positivismo.

Foucault pretende señalar cómo las relaciones de poder atraviesan todo el tejido social, el que a su vez está surcado por los discursos en los que pretende afirmarse la verdad; en este juego de relaciones, el poder se afinca en la verdad y esta a su vez en aquel, equiparable a un camino de doble vía en el que la verdad produce discursos (con la pretensión de ser verdaderos), los que a su vez llevan consigo los mismos efectos que produce el poder ${ }^{29}$. Según ese pensador, la sociedad moderna, la burguesía y el capitalismo crearon mecanismos de control extensivos mediante aparatos de encierro que bien pueden ser instituciones como la fabril, escolar o penitenciaria, instituciones que dominan y controlan la vida de los individuos. Si bien su trabajo más meritorio consistió en haberlo desarrollado y exponer sus redes de operación, no debemos tampoco caer en la idea de creer que ese poder macro pensado por Marx, no tiene mayor relación con el mundo de lo micro, y

Ibíd, pp. 11-12.

Ibíd, p. 12.

29 FOUCAULT, Michel. El orden del discurso. Fábula Tusquets Editores, 2002. evitar caer, como dice Foucault, en el esquematismo de creer que éste está orientado únicamente a reproducir funciones económicas ${ }^{30}$.

Los hallazgos sobre la locura, la panoptización de la sociedad y la sexualidad, desatan una avalancha de investigaciones orientadas de alguna manera a redescubrir el sujeto, abandonado durante mucho tiempo; en este orden de ideas, las disciplinas que se habían ocupado del hombre en general y se habían declarado rabiosamente humanistas, perdieron su centro de gravedad y de paso el objeto mismo de sus reflexiones, por lo que su objeto de estudio adquirió otras connotaciones, orientadas más bien a asumir una postura dominante sobre los sujetos. Tal fue el caso de la medicina y la psicología que asumieron una postura arrogante y salvadora frente a quienes acudían en su ayuda para curar sus dolencias.

No tardaron en advertir entonces muchos de sus detractores, que frente a estas posturas macrosociales, como mecanismos para abordar los problemas de la sociedad, fueron excluyentes; basta mencionar cómo en este esquema interpretativo no se tuvieron en cuenta a las mujeres, minorías étnicas, homosexuales y otros grupos culturalmente marginados; en general, el estudio de estas comunidades fue desestimulado. Un ejemplo clásico de esta situación pueden serlo las culturas indígenas de cualquier país, quienes reclaman el reconocimiento de derechos, no basados en la lucha de clases, como usualmente se les interpretó, sino como el derecho a ser diferente, puesto que comparten una lengua,

$30 \quad$ "Habría que evitar un esquematismo que por otra parte no está en el propio Marx, que consiste en localizar el poder en el aparato del Estado y en hacer del aparato de Estado un instrumento privilegiado, capital mayor, casi único del poder de una clase sobre otra. De hecho, el poder en su ejercicio va mucho más lejos, pasa por canales mucho más finos, es mucho más ambiguo, porque cada uno es en el fondo titular de un cierto poder $y$, en esta medida, vehicula el poder. El poder no tiene como única función reproducir las relaciones de producción. Las redes de la dominación y los circuitos de la explotación se interfieren, se superponen y se refuerzan, pero no coinciden". Texto de Michel Foucault: Tomado de Preguntas a Michel Foucault sobre la geografía, en: Microfísica del poder. Edición y traducción de Julia Varela y Fernando Álvarez Uría. Madrid: Madrid: Ediciones La Piqueta, Tercera edición, 1992. 
visión de mundo, prácticas médicas y hasta chamánicas distintas del común de la población.

"A esto se añadía que, concentrada en los macroprocesos, la historiografía establecida orientada a las ciencias sociales, no tenía ningún interés por los aspectos existenciales de la vida, aquellos que conforman la vida de cada día, con todas sus emociones y temores (aspectos que, sin embargo, ya habían merecido una notable atención por parte de los historiadores de los Annales)"131.

Esto de por sí
representa una
ruptura con
tradiciones anteriores
que vieron en las
continuidades el
fundamento de toda
historicidad posible.
Su pensamiento
-difícil de ubicar por
cierto- se inscribe
más bien dentro de
una crítica histórica
que subvierte el
orden establecido,
como si la historia
estuviera surcada
por una lógica
inmanente.

En lo sucesivo, la forma de hacer historia según los modelos tradicionales se vieron bastante cuestionados, gracias a los aportes del estructuralismo que nos enseñó a ver la historia, no como una visión puramente funcional, sino como estructuras, o claves para entender el desarrollo de cualquier realidad. De ahí se deriva una concepción denominada posmoderna, que despoja a la Historia de toda categoría de cientificidad, para ubicarla más bien como un género literario, como es el caso de Barthes, De Man, White, y Derrida, entre otros pensadores.

Foucault jamás se declaró partidario de los postulados estructuralistas, pues como él mismo lo anunció alguna vez, jamás pretendió cimentar su discurso con base en estructuras, a la manera de Saussure o Levy Strauss, sino que su preocupación residía en buscar las leyes de existencia de sus enunciados. El método de análisis más indicado que construyó para el desocultamiento del sujeto y poder dar cuenta de la realidad del hombre ante la historia lo denominó, ar-

31 IGGERS, George. La ciencia histórica en el siglo XIX. Op., cit, p. 61. queología o método de análisis discursivo, mediante el cual es posible dilucidar el entramado de reglas que constituyen los saberes propios de una época ${ }^{32}$.

Sin desconocer los fundamentos de una historia global, los asume como visiones propias de una época, pero quizás donde radica su mayor aporte son los análisis de capas de población marginal como los vagos, subvalorado por algunas disciplinas. Esto de por sí representa una ruptura con tradiciones anteriores que vieron en las continuidades el fundamento de toda historicidad posible. Su pensamiento-difícil de ubicar por cierto- se inscribe más bien dentro de una crítica histórica que subvierte el orden establecido, como si la historia estuviera surcada por una lógica inmanente. A esta historia se opone Foucault, al centrar sus reflexiones en las prácticas discursivas que generan espacios de poder y dan lugar a prácticas excluyentes. Tal vez por ello, sus libros se niegan a desaparecer de las manos de los historiadores.

\section{VAGOS: EL DILEMA SOCIAL Y LA EXCLUSIÓN}

\subsection{Evolución de la legislación borbónica y neo- borbónica}

Los antecedentes históricos en lo concerniente a los vagos se hallan en la dinastía de los Borbones, monarquía hispánica proveniente de la localidad francesa de Bourbón, ligada a varios tronos, prin-

32 "Se admite que el estructuralismo -expresa Foucault- ha sido el esfuerzo más sistemático para evacuar no solo de la etnología, sino de una serie de otras ciencias e incluso, en el límite de la historia, el concepto de acontecimiento. No veo quién puede ser más antiestructuralista que yo. Pero lo que importa no es hacer con el acontecimiento lo que se ha hecho con la estructura. No se trata de situarlo todo en un cierto plano que sería el acontecimiento, sino considerar que existe todo un escalonamiento de tipos de acontecimientos diferentes que no tienen el mismo alcance, ni la misma amplitud cronológica, ni la misma capacidad de producir efectos. El problema es a la vez distinguir los acontecimientos, diferenciar las redes y los niveles a que pertenecen, y reconstruir los hilos que los unen y los hacen engendrarse unos a otros". FOUCAULT, Michel. Verdad y poder. Diálogo con M. Fontana, en: Un diálogo sobre el poder y otras conversaciones. Selección e introducción de Miguel Morey. Madrid: Alianza Editorial, 2004, p. 144. 
cipalmente al francés y al español que inicia con el reinado de Felipe V, hasta el actual rey Juan Carlos ${ }^{33}$. En ellos existió un esfuerzo por recuperar el nivel nacional perdido desde los tiempos del reinado de Felipe IV, y junto a este proyecto, la necesidad de conjurar la decadencia visible en los altos índices de pobreza, hambre y desarraigo social. Uno de los hitos históricos que hizo notorio el reinado de esta dinastía, fue la expulsión de los jesuitas de los dominios españoles, las conquistas de nuevos territorios, la fundación de sociedades económicas de amigos del país, publicaciones de periódicos y revistas que le imprimieron un despliegue a ciertas disciplinas liberales, la creación de la banca y la fundación de academias, entre otras actividades.

Durante el reinado de Carlos III, el desarrollo de la industria fue una de sus preocupaciones centrales; fortaleció el comercio exterior, la creación del Banco de San Carlos mediante la Real Cédula de 2 de junio de 1872, y el reconocimiento de territorios descubiertos en los siglos XV y XVI. Las políticas diseñadas por Carlos III para contrarrestar la población de vagos en la España de su tiempo fueron severas. En esta población fueron incluidos "desde los gitanos hasta aquellos que concurrían con frecuencia a cafés, botillerías, mesas de trucos, tabernas, etc.". También incluyó en esta categoría de vagos, a "los menestrales y artesanos desaplicados que, aunque tuvieran oficio, no trabajasen la mayor parte del año por desidia, vicios u holgazanería" ${ }^{\prime 34}$. Felipe V ordenó detenciones en masa de vagos y holgazanes, quienes se hallaban en buen estado de salud "eran asignados forzosamente, al servicio de las armas, mientras que los demás eran encerrados en presidios y arsenales". Fernando VI continuó su política de exterminio de vagabundos y mendigos, fue así como dispuso que los más hábiles y de competente edad fueran conducidos "a los regimientos en calidad de

33 Esta dinastía corresponde a los reinados de Felipe $\mathrm{V}$, Luis I, Fernando VI, Carlos III, Carlos IV, Fernando VII, Isabel II, Alfonso XII, Alfonso XIII y Juan Carlos I.

34 Romero de Solís. La población española en los siglos XVIII y XIX. Madrid, 1973. Citado por Luis Miguel Enciso Recio, en la presentación que hace de la obra, El problema de los vagos en la España del siglo XVIII, de Rosa María Pérez Estévez. Madrid: Confederación española de cajas de ahorros, 1976, pp. 14-15. reclutas y los que padeciesen defectos físicos que no les impidiesen el trabajo físico, fueran asignados forzosamente a la construcción de obras públicas. Los enfermos e inservibles fueron los únicos que conservaron su cruel libertad" ${ }^{\prime \prime 3}$.

Las políticas de Carlos III contra la población de vagos y mendigos fueron las más severas de todas, pues a este grupo pertenecieron además "los pretendientes que invadían la corte, los titiriteros y gitanos". La autora señala también cómo fue célebre la "ordenanza de vagos y las levas que aplicaban al servicio del Ejército y la Marina a los ociosos y malentretenidos" ${ }^{\prime 36}$. Las leyes expresadas en la Novísima Recopilación dan cuenta del "modo de proceder a su recogimiento y destino" ${ }^{\prime \prime}$. Posteriormente, bajo esta medida fueron cobijados los caldereros y buhoneros extranjeros que

"vagaban vendiendo efigies de yeso, botes de olor, palilleros, anteojos, cintas, cordones, hebillas, pañuelos, etc.; contra los santeros, saludadores y buhoneros, de nuevo en 1783; contra los que enseñaban cámaras oscuras, marmotas, osos, caballos, perros y otros animales hábiles; y contra lo que a pretexto de estudiantes y con pasaportes de los maestros de escuela o rectores de las universidades, o como romeros y peregrinos, y con pasaporte de los capitanes generales o magistrados políticos de estos reinos, vagaban por ellos" ${ }^{\prime 38}$.

La normativa establecida durante los años de 1725 , 1726, acerca de la manera como se deberían prender los vagabundos, fue enmendada por la de 1773, "en la que se encargaba a las justicias... que detuviesen en las cárceles y custodiasen a los vagabundos hábiles y de edad competente para el servicio

\footnotetext{
35 Ibíd, p. 15
}

36 "Una real orden de 18 de noviembre de 1777 recomendó su persecución y expulsó de la Corte a todos los 'pretendientes'". Ídem.

37 En la Novísima Recopilación, libro XII, título XXXI, se encuentra el conjunto de disposiciones sobre vagos, emanadas en los reinados de Enrique II, Carlos I y Felipe II.

38 PÉREZ ESTÉVEZ, Rosa María. El problema de los vagos en la España del siglo XVIII. Op., cit., p. 15. 
de las armas" ${ }^{\prime 39}$. Una nueva ley promulgada en 1787 "obligaba a recoger a los pobres y mendigos de los sitios reales en el hospicio de Madrid y disponía que los hábiles fuesen enviados a establecimientos para vagos. En el 78 se ordenó retirar a los pobres de sus pueblos y recoger a los de Madrid en su hospicio. La real orden de 24 de diciembre de 1779 resolvió que los vagos destinados a las armas cumpliesen en ella un plazo de ocho años" ${ }^{40}$. Otras medidas segregacionistas emprendidas contra los vagos y buhoneros, fue la prohibición de pasaportes; también fueron obligados a prestar sus servicios en la "marina, hospitales y obras públicas" ${ }^{\prime 1}$. Las leyes de junio de 1784 y la orden de 4 de septiembre de 1785 estuvieron encaminadas a reclutar vagabundos que fueran encontrados "en caminos, lugares y despoblados". Posterior a estas disposiciones, tuvo vigencia la instrucción de 15 de mayo de 1788 en la que se incorporaron algunas de las intenciones propuestas por Fernando VI el 13 de octubre de $1749^{42}$.

El papel asumido por la iglesia fue decisivo en este contexto, en cuanto contribuyó a remediar en parte el pauperismo y la vagancia, al considerar que formaba parte de un deber cristiano ayudar al prójimo; tras esta iniciativa no podía ocultarse el premio celestial o el reino de los cielos, lo que atrajo a una muchedumbre de pordioseros y vagos a las puertas de los templos y conventos. Este sentido de solidaridad -entendida bajo una connotación cristiana de ayuda al prójimo- fue rectificado después mediante la real orden de 7 de junio de 1779 que prohibió a los párrocos y prelados, "la presencia de vagos y mendigos en las puertas de las iglesias y conventos. El corregidor y sus subordinados harían cumplir la orden dada y se haría responsable a párrocos y

39 "Fernando $\mathrm{VI}$, por real ordenanza de 13 de octubre de 1749, encargó a los corregidores 'castigar a los ociosos', no consentir la existencia de 'vagabundos ni gente... sin destino ni aplicación al trabajo' y destinar a estos individuos a las armas o a obras públicas". La real ordenanza, mandada cumplir por Carlos III por real decreto y cédula de 7 de mayo de 1775, establecía que se procediese a hacer "levas anuales... donde se encontraren vagos y personas ociosas para darle trabajo útil". Ídem.

$40 \quad$ Ibíd, p. 16.

41 ídem.

42 Ídem. superiores de los templos y casas religiosas de cualesquiera desórdenes que tuvieran como lugar la concentración de mendigos en sus puertas" ${ }^{\prime 3}$.

Tras presentar una breve síntesis de la legislación española más importante en relación con este tipo de población, es válido indagar por qué cuando se hace referencia a ellos, se asocie esta tipificación a poblaciones como mendigos, malhechores y sin oficio, se le atribuye a esta expresión una connotación de peligrosidad y delincuencia, de donde se deriva la necesidad de ser segregados y conminados a ser útiles.

"Hasta 1875 se persigue y se aprende en calidad de vagos a los que no tienen oficio, ni hacienda, ni rentas y viven sin medios de subsistencia conocidos. Otros individuos conceptuados como vagos son: cuantos carecen de oficio o no lo ejercen sin motivo justo, los jornaleros que no trabajan con continuidad, los que frecuentan casas de juegos, lugares sospechosos o de mala reputación; los amancebados, jugadores y borrachos, los que dan mala vida a su mujer, desobedecen a sus padres o no les ayudan en el trabajo"44.

Cabe señalar cómo este catálogo ya venía incrementándose por los años de 1745, pues a esta tipología fueron incluidos "los falsos peregrinos y romeros, a los mozos que consumen gran parte de su tiempo en ferias, fiestas, y romerías y a los malos estudiantes, afanados en lograr un título para mantenerse en una vida licenciosa, gozar del fuero académico o de los efectos de la holgazanería ${ }^{45}$. También esta legislación contempla las conocidas levas de vagos o recogidas donde eran tomados por sorpresa o mediante denuncia previa, los vagos o sospechosos de serlo. La legislación española fue notoria por demás en lo relacionado con asuntos de vagancia, como lo

\footnotetext{
43 Otras órdenes promulgadas luego, establecían las maneras "de recoger a los mendigos y de dar socorro a los pobres, y por reales órdenes y bandos publicados en Madrid en 1783, 1786, 1789, 1790, 1791 y 1798 sobre recogimiento de pobres mendigos y vagos, socorro de los vergonzantes y expulsión de los forasteros". Ibíd, p. 17.

44 Ibíd, p. 20

$45 \quad$ Ibíd, p. 27
} 
refleja en buena medida el reinado de Felipe $V$ y sus sucesores.

La vagancia no era actividad meramente masculina, como lo reflejan las diligencias en relación con el juicio seguido en Bogotá contra Evangelina Buitrago y Agustina Riaño en 1907, pena que debieron cumplir las sindicadas en la Colonia Penal del Meta. Dentro de los cargos formulados a Evangelina Buitrago se encontraban los de "hurto, amenazas, escándalo y vagancia ocho veces". En la indagatoria confiesa "que hace como dos años que no está sirviendo en ninguna parte; que ha estado en el Panóptico sufriendo pena por dos años, por hurto; y que no tiene con quién comprobar que sea mujer honrada y trabajadora"46. Agustina Riaño, la otra sindicada, "confiesa que ha sido llevada unas tres veces a la Policía, por sospecha de hurto; que vive con un hombre llamado Juan Bautista Cruz; y que hace como un año que no ha servido en ninguna casa, pero que ha ido a lavar donde algunas familias conocidas". Las penas impuestas no fueron iguales aunque estaban cobijadas por la misma norma (Artículo $6^{\circ} \mathrm{del}$ decreto No 928 de 1907). Evangelina Buitrago tenía el agravante de vérsele como una mujer "completamente desmoralizada y avezada a los malos hábitos; y en la Riaño se nota apenas la falta de moralidad pero no ensenegamiento (sic) completo en el vicio". El fallo proferido contra las condenadas, fueron de un año y tres meses, respectivamente.

No es prolífica la información documental que estipule la doble condición de vago asociado a delitos como robo, pero suponemos que se dieron en algunas situaciones. Un caso de esta naturaleza es el juicio que se le siguió a Ezequiel Cagua por el delito de vagancia sumado al de hurto, por sustraerle el día 5 de febrero de 1907 en la población de Chipaque, la suma de $\$ 800$ al señor Adolfo Daza. "Los testigos Manuel Rodríguez, Lisandro Zapata, Joaquín Ángel y Eugenio Becerra, acreditan que al nombrado Cagua se le conoce generalmente en Chipaque con

46 Diligencias en relación con el juicio seguido contra Evangelina Buitrago y Agustina Riaño, por vagancia. A.G.N. Sección: Archivo Anexo II. Fondo: Ministerio de Guerra. Serie: Asuntos Judiciales, Procesos. Caja: 2. Carpeta 4. Año 1907. Folios 1-11. el sobrenombre de "El Gallinero", motivado por sus frecuentes raterías, y Eugenio Rodríguez dice que en el tiempo que estuvo de Inspector de Policía de esa población, lo hizo conducir varias veces a la cárcel por ratero. Aparece igualmente estable [Fol. 25v] cido en el sumario, que el nombrado individuo no tiene oficio que le sea conocido y vive sin saberse los medios lícitos y honestos de donde le venga la subsistencia" 47 . Posteriormente se encontró anexo al documento, una nota donde se decreta la libertad del condenado el día 17 de junio de 1908 en la colonia penal y militar del Meta.

Como antecedentes históricos que ameritan ser tenidos en cuenta para la adopción de modelos normativos -y más que esto- para señalar la ausencia de una tipología del vago que pueda proporcionar elementos claves para su definición, se citan algunas de la leyes y decretos más representativos que nos ayudan a entender su desarrollo. Así por ejemplo, el auto de 1715-1718 y el bando de policía de 1782 hace referencia a "vagos, mendigos, mal entretenidos, mujeres públicas, niños expósitos y pobres", lo que parece señalar que era más cómodo hacer imputables a varios tipos de población cuando la normatividad no era muy clara ${ }^{48}$. La legislación es-

47 Diligencias en relación con el juicio seguido contra Ezequiel Cagua por vago. A.G.N., Sección: Archivo anexo II. Fondo: Ministerio de Guerra. Serie: Asuntos Judiciales, Procesos. Caja 1, Carpeta 1. Año: 1895-1908. Folios: 2328. "El juicio se encuentra acompañado de las declaraciones de Eugenio Rodríguez, quien aseveró que durante "el tiempo que estuvo de inspector de policía en esa población, lo hizo conducir varias veces a la cárcel por ratero".

En vista de esto y de acuerdo con lo dispuesto en el Decreto de Alta Policía Nacional y Circular del Excelentísimo Señor Presidente de la República de 28 de enero de 1905 la Gobernación administrando Justicia en nombre de la República y por autoridad de la Ley, Resuelve:

Declárase vago a Ezequiel Cagua y en esta virtud, de acuerdo con lo dispuesto en el artículo 491 del Código de Policía, condénasele a trabajar en obras públicas o a la Colonia Penal que indique el Señor Ministro de Guerra, a elección de este alto empleado, por el término de un año, a efecto de procurar su enmienda y corrección".

$48 \quad$ Citado por DÍAZ MUÑOZ, Eliana, en: El hospicio Real en la ciudad de Santa Fé y el nacimiento de la asistencia pública 1750-1850. Trabajo de grado presentado como requisito para obtener el título de historiadora. Pontificia Universidad Javeriana, Bogotá, 2005, p. 1. Posteriormente, la Ley 18 de mayo de 1841 sobre Policía General y sus 
pañola hace explícitas también estas imprecisiones como lo contempla la Real Orden del 30 de abril de 1745, donde se hacía referencia a "vagos, ociosos y malentretenidos"; del mismo modo, la Recopilación de Indias de 1680 "identificó a los vagabundos con sectores tradicionales de la sociedad española como los gitanos, identificados con la vida errante" ${ }^{\prime 49}$. Además de estas, se identificaron otras que hacen mención a la mendicidad y la vagancia, a saber:

- Auto de 1715-1718 y el bando de policía de $1785^{50}$. Ley 3 de mayo de 1826 , sobre las causas de hurto y robo.

- Ley de 6 de abril de 1836, sobre el modo de proceder contra los vagos y en las causas de hurto de menor cuantía.

- Código Penal de 1837.

- Ley de 18 de mayo de 1841, sobre Policía General, y las reformas posteriores de 1843 y 1846.

- Ley de 29 de mayo de 1843, adicional a la de Manumisión (Ley de 21 de julio de 1821).

- Ley de 14 de junio de 1842, adicional a la de Policía General (Ley de 18 de mayo de 1841).

\subsection{Tipología del vago y movilidad geográfica}

Las investigaciones historiográficas realizadas en torno al tratamiento de la pobreza -principalmente en la tradición europea donde ha suscitado más
La primera hace

énfasis en una

connotación

religiosa, a

diferencia de la

segunda que tiene

una orientación

laica. reflexiones este tema- ha ubicado el concepto de pobreza dentro de una connotación más sociológica aunque poco precisa, señalando la distinción entre caridad y filantropía. La primera hace énfasis en una connotación religiosa, a diferencia de la segunda que tiene una orientación laica.

reformas de 1843 y 1846, contempla el modo de proceder en el abordaje de vagos y delincuentes menores.

49 JURADO, Juan Carlos. Vagos, pobres y mendigos. Contribución a la historia social colombiana 1750-1850. Medellín: Editorial La Carreta, 2004, p. 41.

50 AGN. Sección: Colonia. Fondo Real Audiencia - Cundinamarca, T. 11, Folios 894-906.
En el centro de la discusión se encuentra una masa poblacional en condiciones de vulnerabilidad social que requiere protección. Dentro de esta tipificación, junto con los mendigos, lazarinos y locos, los vagos han formado parte de este espectro de población menesterosa, privilegiada en esta investigación.

Ante la ausencia de una tipología que en sentido estricto caracterice a los vagos, se incorporan expresiones ligadas como "vago y pernicioso", "vagos y rateros", "delito de vagancia y ladrón consuetudinario", y en su mayor parte, sencillamente "vagos". En junio 14 de 1905 fue detenido y puesto en el panóptico de la ciudad de Bogotá, el señor Pedro Tribiño "por el delito de vago y pernicioso". En primera instancia fue incluido en la lista de los destinados para marchar a las Islas de San Andrés, pero su inhabilidad "para el servicio militar por estar enfermo de elefancia de los griegos", fue conducido a la Colonia Penal del Meta, donde purgó una pena de doce meses ${ }^{51}$.

Con la creación de la Policía Nacional en 1890, justo en lo relacionado con su participación como organismo de vigilancia en las Colonias Penales, los mecanismos de control se hacen más evidentes, con lo que de paso se abandona la idea de ayuda benévola, y de nuevo la frontera entre vagos y mendigos parece desdibujarse al ser asimilados a delincuentes. Hacia 1920 estos mecanismos de control se hacen más notorios con la proliferación de sitios de encierro, en donde el trabajo se concibe como proceso socializador. Así pues, la adopción de nuevas políticas conduce a que los vagos sean confinados a las cárceles, en tanto que los mendigos son re-

51 Diligencias contra Pedro Tribiño, por el delito de vago y pernicioso. A.G.N. Sección: Archivo, Anexo II. Fondo: Ministerio de Guerra. Serie: Asuntos Judiciales, Procesos. Caja 3. Carpeta 1. Año 1905. Folios 33-37. Otros casos son los denominados "delito de vagancia y ladrón consuetudinario". (Diligencias relacionadas con el juicio seguido contra Carlos Estévez por el delito de vagancia y ladrón consuetudinario. A.G.N. Sección: Archivo, Anexo II. Fondo: Ministerio de Guerra. Serie: Asuntos Judiciales, Procesos. Caja 2. Carpeta 4. Año 1907. Folios 17-40). Otros delitos de vagancia se encuentran asociados al de ser rateros (Diligencias en relación con el juicio seguido contra José del C. Rodríguez, Ricardo Lugo y Eloy Orjuela, por vagos y rateros. A.G.N. Sección: Archivo Anexo II. Fondo: Ministerio de Guerra. Serie: Asuntos Judiciales, Procesos. Caja 3. Carpeta 3. Año 1903. Folios 119-124). 
cluidos en asilos. El Código de Policía de 1922 hace más visible la distinción entre vagos y pobres en los siguientes términos:

"Repútanse vagos: a los que sin tener oficio ni beneficio, hacienda o renta, vivan sin ocupación lícita $u$ otro medio legítimo de subsistencia, y cuyos malos antecedentes legales, por delitos contra la propiedad, estén comprobados plenamente; a los que mendigan públicamente contra la prohibición de la policía y sin inconvenientes graves para trabajar, a juicio de dos facultativos nombrados por el funcionario que conozca el caso, a falta de dichos facultativos podrá nombrarse a dos personas honorables del vecindario; a los ebrios consuetudinarios, debiéndose acreditar este hecho con declaraciones de personas honorables del vecindario, siempre que aquellos no tengan oficio ni beneficio, ni otro medio lícito de subsistencia; los que hayan sido condenados por tres veces por alguna autoridad, como violadores de disposiciones sobre juegos prohibidos, e incurran nuevamente en la misma falta; los que sean convictos de proyecto o proyectos fingidos de falsificación de moneda o de documentos de crédito bancario o del Estado; y toda persona bajo cuya dirección, protección, consejo o ayuda, otra persona ejerza la prostitución pública o privadamente" 52 .

En Colombia se adoptaron medidas similares a las españolas como lo expresa el código de 1914, en donde se reitera el propósito de conminarlos a trabajar en la apertura de carreteras, construcciones de caminos y obras estatales. Por aquellos años, la normatividad existente es mucho más explícita que en el siglo anterior, lo que presenta una tipificación más explícita, asociada al hecho de no tener oficio ni profesión, ser ebrio habitual, o recurrir con frecuencia a juegos prohibidos; además, figura dentro del ámbito de las ociosas, "las mujeres públicas y escandalosas", lo que se presta a confusión. Este código hace extensiva la categoría de vago a "los oficiales, jornaleros, aprendi-

52 Ordenanza $N^{\circ} 22$ de 1922 sobre reformas del Código de Policía, en: Compilación de Leyes y Ordenanzas de la Beneficencia y Asistencia Social de Cundinamarca. 18601942. Bogotá, 1942. Citado por Beatriz Castro en: Caridad y beneficencia. Op., cit., p. 74 . ces y sirvientes que pierdan en la ociosidad parte del tiempo", "los que andan de pueblo en pueblo" y "el ratero que durante un año haya tenido que castigar dos veces la policía". Es manifiesta la idea que la actividad natural del hombre debe estar encaminada a la producción de bienes materiales, donde el ocio no es censurable sino punible.

La pobreza generalizada fue uno de los factores asociados a la movilidad geográfica, seguramente ante la incapacidad de vincularse a la dinámica económica, situación que posibilitó su inclusión dentro de la tipología de vagos, a los mendigos y delincuentes. La ayuda que pudiera brindársele a estos menesterosos adquiría el matiz filantrópico de inversión, interés que se traducía en el bienestar de la sociedad. Uno de los estudios relacionados con la movilidad geográfica fue el realizado por Julián Vargas, quien asevera que a mediados del siglo XVIII proliferaban en Santafe, vagos, prostitutas y mendigos, "como resultado de la excesiva migración a la ciudad de crecientes grupos de mestizos y la movilidad geográfica de la población" ${ }^{\prime 53}$. Miguel Samper un liberal del siglo XIX, hace una descripción de la sociedad capitalina en su obra clásica La miseria en Bogotá, de mediados del siglo XIX en los siguientes términos: "Las calles y plazas de la ciudad están infestadas por rateros, ebrios, lazarinos, holgazanes y aun locos" ${ }^{\prime \prime 4}$. Su obra en general ha sido considerada como un aporte a la sociología y al pensamiento social y económico colombiano.

La movilidad de la sociedad rural a lo largo del siglo XIX a la población de Santafé, también ha sido estudiada por Alberto Martínez Boom, al señalar los cambios producidos en función de la pobreza, al punto de llegar a constituirse en un "problema de policía" urbano. En el reinado de Carlos III (1759-1788), la legislación orientada a corregir la vagancia y la mendicidad, fue asumida por las figuras más prestantes de

3 JURADO, Juan Carlos. Vagos, pobres y mendigos. Op., cit., p. 21.

54 SAMPER, Miguel. La miseria en Bogotá. Bogotá: Imprenta Gaitán, 1867. El Instituto Colombiano de cultura hizo la reedición de esta obra en 1977 bajo el título de Selección de escritos. Bogotá, p. 31. 
su reinado como el Conde de Aranda, Campomanes, el Conde de Floridablanca y Jovellanos.

"Al ser desacralizada, la pobreza es puesta en el orden de lo práctico, y se tratará entonces de organizarla atacando la ociosidad de los vagabundos, asistiendo y encerrando a los mendigos y enfermos, y convirtiendo a los pobres en seres útiles para la sociedad mediante el trabajo" 55 .

El Hospicio Real de la
ciudad de Santa Fe,
es un ejemplo de esta
situación; excluido por
demás del sistema de
beneficencia, el hospicio
fue -como lo enuncia
Foucault- "aparato de
observación, de registro
y de encauzamiento de
la conducta"

Los hospicios algunas veces fueron utilizados como centro de reclusión de la población marginal. El Hospicio Real de la ciudad de Santa Fe es un ejemplo de esta situación; excluido por demás del sistema de beneficencia, el hospicio fue -como lo enuncia Foucault- "aparato de observación, de registro y de encauzamiento de la conducta"56. Como institución que albergó a "pobres, vagos y mendigos" a finales del siglo XVIII, se consideró esta ayuda en el sentido de caridad cristiana, ligada al concepto de virtud teológica.

\subsection{Leyes sobre concertaje de vagos}

Junto al despliegue que tuvieron las ciencias naturales en el siglo XVIII, surgió también un interés por el trabajo; la actividad humana fue concebida en función de la productividad, tanto que el sentido mismo de la expresión ocio fue asociada a la

JURADO, Juan Carlos. Vagos, pobres y mendigos. Op., cit, p. 22.

56 FOUCAULT, Michel. Vigilar y Castigar. Op., cit, pp. 145178. pérdida de tiempo y por ende, al trabajo improductivo. La vagancia -muy cercana a esta connotación semántica- fue duramente controlada y reprimida en la dinastía de los borbones, de donde se derivó la idea de la resocialización social mediante el trabajo. "Los infractores antes eran enviados a servir en las milicias reales en Cartagena, y luego debían ser enviados a los ejércitos de la naciente república. En otras ocasiones eran destinados a trabajar en las obras públicas o confinados a las poblaciones de reciente fundación" ${ }^{\prime 57}$.

La conversión de vagos en trabajadores productivos fue reforzada por disposiciones no solo de orden local, regional, sino también peninsular, como lo expresa la real cédula de 2 de agosto de 1780 que estimuló la fundación de poblaciones, conminando a la población de vagos a adoptar patrones de asentamiento. El docente investigador Arístides Ramos, que ha investigado la región del Carare y su relación en función del orden económico regional, señala cómo en la provincia de El Socorro se "estableció un presidio rural para emplear a los reclusos en los trabajos del camino, aportando los contratistas el alimento para los presidiarios como también medio real para su vestuario y demás costos. La construcción del camino se verificó en los términos propuestos y el gran esfuerzo en la primera mitad del siglo XIX se dirigió a su poblamiento"58.

Las medidas judiciales acerca del concertaje de vagos destinados al poblamiento de algunas fronteras de colonización, tenían la clara intención de corregir las desviaciones de los ociosos y promover valores éticos acerca de la importancia y la necesidad del trabajo. El siguiente cuadro registra los concertados que fueron llevados para formar los núcleos poblacionales de Chucurí, en 1847.

57 JURADO JURADO, Juan Carlos. Vagos, pobres y mendigos. Op., cit., p. 14.

58 RAMOS PEÑUELA, Aristides. Los caminos al río Magdalena. La frontera del Carare y el Opón 1760-1860. Bogotá: Instituto Colombiano de Cultura Hispánica, 2000, p. 138. 
Personas remitidas a las nuevas poblaciones de Chucurí a servir como concertados. Año 1847

\begin{tabular}{|l|c|c|}
\hline \multicolumn{1}{|c|}{ CANTONES } & HOMBRES & MUJERES \\
\hline Socorro & 3 & 9 \\
\hline San Gil & 1 & 1 \\
\hline Barichara & 4 & - \\
\hline Charalá & 4 & 6 \\
\hline Oiba & - & - \\
\hline Zapatoca & - & - \\
\hline Totales & 12 & 16 \\
\hline
\end{tabular}

Fuente: A.G.N. Gobernaciones Varias, 135, f. 471r. Citado por Aristides Ramos en: Los caminos al río Magdalena. Op., cit., p. 145.

A mediados del siglo XIX, estas medidas restrictivas conocidas como concertaje de vagos y penas por vagancia, fueron perdiendo vigencia, cuando el pensamiento liberal conquistó espacios políticos y se promovió la idea del libre mercado, hasta ser finalmente derogadas en $1851^{59}$. A esta élite de intelectuales liberales perteneció Manuel Ancízar, ${ }^{60}$ quien hizo manifiesto su rechazo ante la adopción de estas medidas, y pidió a cambio la capacitación de "holgazanas y viciosas", en oficios que les pudiesen generar ingresos.

La visión del trabajo como resocialización de las malas conductas, es una constante en este tipo de documentos, como lo refleja la exposición que presenta el Secretario del Interior Lino de Pombo ${ }^{61}$, ante el Congreso en 1835 en donde señalaba lo siguiente:

59 Las penas por vagancia fueron derogadas por la élite liberal a mediados del siglo XIX, véase Gaceta Oficial, Bogotá, sábado 3 de mayo de 1851, No. 1219. Ver cuadro Nº 16. Ibíd, p. 148.

60 Ibíd, p. 146.

61 BENÍTEZ MORALES, Otto. Bases históricas y doctrinarias del régimen social y del subsidio familiar en Colombia. Bogotá: Caja Colombiana de Subsidio Familiar (Colsubsidio), 2001. Vol. 2, p. 170. En otro de sus apartes señalaba lo siguiente: "Actualmente los vagos calificados como tales, después de un juicio en que a la mayor parte les es fácil producir supuestas pruebas de que no lo son, o gubernativamente, van destinados al servicio en el ejército o en la Marina, si el juez o la autoridad política en su caso, cuidan de perseguirlos; empero, es tan reducido el personal de nuestra marina y de nuestro Ejército, en donde no puede recibirse a los vagos sino en cierta proporción
"Todos los esfuerzos que se hagan para extirpar estos azotes de la sociedad, y para rehabilitar en ella la multitud de individuos que en calidad de vagos y de mendigos la sirven ahora de molesta carga, serán otros tantos pasos importantes en favor de la moral, de la industria y de la riqueza nacional. Al hacer honrado y laborioso, quizá contra su voluntad, a un hombre que por la desfavorable influencia de las circunstancias, por los vicios de la educación, por falta de estímulos o por natural indolencia había contraído el hábito funesto de la ociosidad, no es a él solo a quien se beneficia; se adquiere un nuevo agente de producción, quitándolo a la depravación de costumbres; y se transforma en un buen padre de familia y en un apoyo de la libertad y desorden al que entraría en todo plan de trastorno para medrar a costa ajena, y solo serviría para sí olvidando hasta los deberes naturales. Una buena ley de policía, bien cumplida, produciría, entre otros, este resultado provechoso, si su ejecución quedaba encomendada a los funcionarios del orden político; y serviría de apoyo a lo que en el mismo sentido trabajan con celoso pero poco eficaz interés las cámaras de provincia y los concejos municipales".

Los documentos encontrados en lo tocante a asuntos de vagancia son bastante significativos y variados, contemplan desde abusos cometidos por autoridades regionales, reclamaciones y desatención ante peticiones solicitadas. La marginalidad y la exclusión social en relación con los "vagos y malentretenidos" fue severa, y considerada además causal para no ser tenidas en cuenta las declaraciones en calidad de testigo, como el acaecido en la ciudad

prudente y cuando sea físicamente aptos para el servicio, que si se persiguiese a éstos con la eficacia debida no habría cabida para ellos en ninguna de las dos armas; y por otra parte, siendo de una misma clase la pena o corrección para todos, necesariamente ha de ser desigual e injusta con frecuencia en la práctica. Parece que deberían establecerse ciertas graduaciones en esa pena o corrección, dejando hasta cierto punto discrecional su aplicación a las respectivas autoridades políticas locales; y que el aprendizaje forzado de algún oficio, el oficio doméstico de la misma naturaleza, el trabajo a ración en las obras públicas de las provincias o cantones, el servicio militar, y las colonizaciones lejanas, fuesen los destinos de los vagos, atendidas sus diferentes circunstancias". 
de Honda el 15 de diciembre de 1824 contra José María Samper, por el delito de agresión física contra del cura del pueblo. Para tales efectos se recibió la declaración del vecino Manuel Baldire, quien aseguró haber sido testigo ocular de la agresión recibida contra el sacerdote. El testimonio fue rechazado por el incriminado Samper, al afirmar que se trataba de un "vago y malentretenido", causal que ameritaba no ser tenida en cuenta como parte del acervo probatorio ${ }^{62}$.

Los excesos de las autoridades que ejercieron funciones en localidades, trascendieron algunas veces surgieron a raíz una rencilla que tuvo Lucas con el hijo del alcalde, situación por la que fue inculpado de vago y puesto en manos de la antigua Prefectura de Bogotá y recluido luego en prisión
Los problemas al terreno de lo personal; tal es el caso del alcalde de Chía en 1905 que inculpó a Lucas Gordo de ser vago, no obstante haber afirmado los testigos que el inculpado posee propiedades y sostiene con su trabajo a su madre. Los problemas surgieron a raíz de una rencilla que tuvo Lucas con el hijo del alcalde, situación por la que fue inculpado de vago y puesto en manos de la antigua Prefectura de Bogotá y recluido luego en prisión. Tras permanecer varios meses en la cárcel fue incorporado a las milicias de la República, en el batallón Bomboná. Benita Canasto, viuda y madre de Lucas Gordo, en una petición elevada ente el Ministro de Guerra, propone que en lugar de su hijo, destinado a servir en las milicias, sea remplazado "en lugar de mi hijo enfermo, por un joven robusto, adelantado en el arte militar, alentado y apto para la carrera, llamado Ángel, antiguo militar en las fuerzas del Gobierno; quien voluntariamente, y en atención a su penosa situación, y a la suma pobreza del Señor Ángel, ha ofrecido colocarse en el Batallón Bomboná, en remplazo de mi hijo"63.

62 A.G.N. Sección República. Fondo Asuntos criminales, folios 163-244, 283-365 y 479-489.

63 Benita Canasto, madre de Lucas Gordo, solicita se le conceda la baja de éste, o se le admita un remplazo. A.G.N. Sección: Archivo Anexo II. Fondo: Ministerio de Guerra.
En otras situaciones podía ocurrir que un inculpado empezara a cumplir la pena, sin conocer de antemano el tiempo de su condena. En una petición elevada ante el Ministro de Guerra, Milcíades Galarza, que se encontraba recluido en la Colonia Penal del Meta, en 1907, expresaba lo siguiente:

"Hace dos años y un mes que resido como preso en esta Colonia, sin que hasta el presente haya podido conocer el tiempo a que fui destinado; incertidumbre ésta que viene aniquilando mi espíritu y que por consiguiente minará hasta destruir mi salud, sin alcanzar antes el consuelo de ver a mi familia, de la que nada he sabido en mi confinamiento y la que por completo ignora mi suerte, como que no he querido informarlos de mi proscripción"64.

La solicitud prosperó, teniendo en cuenta las consideraciones del Jefe de la Colonia, quien certificó que Milcíades Galarza ha observado buena conducta y prestado sus servicios con interés y provecho. De conformidad con lo anterior, le fue expedido el pasaporte de libertad.

Las declaraciones de alguien que pudiera atestiguar mala conducta o ejercer la vagancia o el raterismo de un vecino suyo, era motivo de apresamiento para ser enviado luego a las colonias penales. En junio de 1905 fue remitido Abraham Cuervo, por el alcalde de Tocancipá a la Jefatura de comandancia, a quien se le sindicaba de ser un individuo de mala conducta, vago y ratero; fue considerado además tahúr, lo que representaba una amenaza para la población. Finalmente, el 15 de junio del mismo año, Abraham Cuervo fue incorporado en el Batallón Calibío en calidad de zapador 65 .

Serie: Asuntos Judiciales, Procesos. Caja: 3. carpeta 1. Año 1905. Folios 102-115.

64 Oficio del Alcalde Provincial de Sumapaz contra Rafael Portilla y Milcíades de Galarza, como vagos y perniciosos. A.G.N. sección: Archivo Anexo II. Fondo: Ministerio de Guerra. Serie: Asuntos Judiciales, Procesos. Caja 3. Carpeta 1. Año 1905. Folios 125-127.

65 Diligencias contra Julio y Manuel Contreras por el delito de vagancia. A.G.N. Sección: Archivo Anexo II. Fondo: Ministerio de Guerra. Serie: Asuntos Judiciales, Procesos. Caja 3. Carpeta 1. Año 1905. Folios 1-6. 
En los procedimientos seguidos por las autoridades contra algunos inculpados, no se descarta la posibilidad de haber obrado con excesos; tal es el caso de las diligencias realizadas contra los hermanos Julio y Manuel Contreras, incriminados del delito de vagancia quienes elevan una petición al Señor General, D. Euclides Angulo, en donde solicitan su libertad. Los inculpados argumentan lo siguiente: "No es justo, ni humanitario Señor General, que se mantenga padeciendo, a dos jóvenes, que han sacrificado todo, por acudir a los campos de batalla, en defensa del Gobierno, y en disputa de sus derechos, para que así se vean vulnerados, y que sin un móvil que lo justifique, se les aplique el cruento tormento de privarlos de la libertad" 66 . Si bien, no existen mayores registros en el documento que den cuenta de sus actividades o formación, sorprende el buen estilo y los principios invocados. En uno de sus apartes expresa lo siguiente:

"Hace poco más de dos meses fuimos conducidos a la Policía Nacional por orden de su Subdirector, y por haber reclamado, en uso de mis derechos, como ciudadano, y después de nueve días de mi procedimiento, fui conducido al Panóptico en unión de un hermano mío, sin que hubiera contra nosotros la acusación más leve. Cosa excepcionalmente singular pasa en el modo como se han violado las leyes, desconociendo nuestros derechos, pues en ninguna parte del mundo civilizado, Señor General, se juega al azar y por capricho, con la suerte de un individuo, sin que para ello haya motivo legal que lo merezca. Tengo conciencia, Señor General de no haber delinquido en el cumplimiento del deber y aún menos, que sobre mi conciencia recaiga el peso del delito" 67 .

El día 29 de junio fueron puestos en prisión, tras seis días de permanecer incomunicados, no sin antes poner de presente las vejaciones padecidas en el panóptico de la capital. Manifiestan los hermanos Contreras, ser admiradores de las instituciones y haber participado como soldados en el Batallón Caro, "ya como Ayudante del General Paulo E. Escobar, en

\footnotetext{
66 Ídem

67 Ídem.
}

la pasada contienda política, ya como expedicionario cuando a la Patria amenazaba peligro. Además, un hermano mío ultimó su vida en los campos de batalla, también en defensa de nuestros ideales políticos"68. El día 24 de junio de 1905, el Estado Mayor General advierte según el oficio 3498 que por orden del Director General de la Policía Nacional fueron puestos en libertad, pero sorprende que una solicitud posterior con fecha de julio 5 de 1906, -es decir poco más de un año después- Julio Contreras solicitó de nuevo su libertad, lo que nos induce a pensar que su reclusión tardó más de lo esperado.

Los Códigos de Alta Policía, contemplaban por los años de 1908 , la rebaja de penas para quienes hubieran tenido buen comportamiento en los sitios de reclusión, como es el caso de la petición que eleva Ismenia L. de Estévez, madre de Carlos Estévez, quien se hallaba confinado en la Colonia Penal del Meta durante 22 meses, de los que apenas le faltaban dos

La comisaría estimó conveniente concederle la libertad, dado que cumplía con lo estipulado en los Códigos de Policía, como era mantener buena conducta durante su permanencia en las colonias, y haber cumplido las dos terceras partes de la sentencia impuesta relacionados con el juicio seguido al imputado fueron vagancia y ladrón consuetudinario. Finalmente, la comisaría estimó conveniente concederle la libertad, dado que cumplía con lo estipulado en los Códigos de Policía, como era mantener buena conducta durante su permanencia en las colonias, y haber cumplido las dos terceras partes de la sentencia impuesta. Además argumentó que "con el tiempo de pena que ha sufrido, ha podido corregirse y adquirir hábitos para el trabajo, y por tanto le concede la rebaja que solicita"69.

\footnotetext{
8 Ídem

69 Diligencias relacionadas con el juicio seguido contra Carlos Estévez por el delito de vagancia y ladrón consuetudinario. A.G.N. Sección: Archivo Anexo II. Fondo: Ministerio de Guerra. Serie: Asuntos Judiciales, Procesos. Caja 2. Carpeta 4. Año 1907. Folios: 17-40. En la actualidad,
} 


\section{4. Fronteras de colonización}

Las fronteras o tierras de nadie configuran un espacio geopolítico donde la necesidad primordial consiste en la imposición del orden. Estos espacios geográficos invisibilizados debieron ser incorporados a la lógica del progreso y la dinámica estatal. Ahora bien, ¿cómo se traduce en la práctica estas dinámicas y políticas de incorporación? El Estado capitalista con su lógica avasalladora e idea de progreso establece mecanismos de control en aquellos mundos marginales, la mirada entonces se despliega bajo la óptica de la incorporación de los no lugares, o zonas que ameritan ser rehabilitadas ${ }^{70}$.

la única colonia penal agrícola existente se encuentra a cinco kilómetros del perímetro urbano de la población de Acacías, Meta, en el oriente colombiano, fue creada mediante Resolución No. 01286 del 4 de mayo de 2001 e inaugurada en agosto de 2001 en el mandato presencial del doctor Andrés Pastrana. En Colombia, el sistema penitenciario se encuentra bajo la Dirección General del INPEC (Instituto Nacional Penitenciario) que regula el funcionamiento de estos centros. No existe distinción alguna entre la concepción republicana del trabajo como resocialización y la normatividad actual como estipula el artículo 79 de la Ley 65 de 1993, como se expresa a continuación: "El trabajo en los establecimientos de reclusión es obligatorio para los condenados como medio terapéutico adecuado a los fines de la resocialización. No tendrá carácter aflictivo ni podrá ser aplicado como sanción disciplinaria. Se organizará atendiendo las aptitudes y capacidades de los internos, permitiéndoles dentro de lo posible escoger entre las diferentes opciones existentes en el centro de reclusión. Debe estar previamente reglamentado por la Dirección General del Instituto Nacional Penitenciario y Carcelario". Citado por Omar Huertas Díaz, Lynda Layda López Benavides y Carlos Mario Malaver Sandoval en: Comunidad terapéutica y programa penitenciario: Colonia Penal de Oriente. Criterio Jurídico Garantista, año 3, N 5, julio-diciembre de 2011, pp. 6886. Revista de la Facultad de Derecho de la Fundación Autónoma de Colombia (FUAC). De los mismos autores ver: Colonias penales agrícolas de los siglos XIX y XX como sustitución de la pena de prisión tradicional en Colombia. Revista Criminalidad. Policía Nacional. Dirección de Investigación Criminal e Interpol. Volumen 54, número 1. Enero-junio de 2012, pp. 313-338.

70 La idea de utilizar la mano de obra de población de vagos, no es un caso típicamente colombiano. La literatura existente sobre el tema puede ser complementada con las siguientes obras: RIVAROLA, Milda. Vagos, pobres y soldados. La domesticación estatal del trabajo en el Paraguay del siglo XIX, Asunción, Centro paraguayo de estudios sociológicos, 1994. Las leyes de la vagancia al servicio de las economías exportadoras pueden verse en David McCreery "Wage Labor Free Labor, and Vagrancy Laws: The transition to Capitalism in Guatemala, 1920-
El profesor Ramos señala cómo la expansión de la frontera de la región del Carare hacia el Valle del Magdalena a finales del siglo XVIII estuvo asociada a la fundación de parroquias. Las tierras inexploradas y potencialmente productivas, en donde fueron halladas riquezas auríferas, estimularon la apertura de caminos y establecimientos de redes de circulación comercial. Las élites locales que formaron parte de los nacientes núcleos fundacionales generaron un interés inusitado por la tierra, lo que se tradujo en el desarrollo de la agricultura como potencial de exportación. Algunos colonos que lograron la consolidación de empresas productivas fueron beneficiados con mano de obra de vagos, entre ellos Aquileo Parra, quien celebró un contrato con el gobernador de la provincia, Manuel María Zaldúa en 1847 en los siguientes términos:

"1. Recibir los vagos condenados por este delito hasta por seis años, a condición de ser robustos para soportar el clima y el trabajo.

2. Una vez recibido el vago en concierto, éste no podrá ser desechado hasta terminar el tiempo de la condena.

3. Los empresarios asumen los gastos de mantenimiento, medicinas en caso de enfermedad y gastos de conducción.

4. El trabajo de los vagos será nuestra única retribución.

5. En caso de castigo no será más de 25 azotes, en caso de penas graves serán remitidos a la autoridad. 6. En caso de fuga los empresarios responderán ante la Cámara Provincial con una multa de 50 pesos"17.

Desde los tiempos coloniales se ha podido advertir un escaso control del gobierno central en los territorios de periferia, lo que dio lugar a la configuración de espacios inhóspitos que la literatura asoció desde entonces a "territorios de refugio para las poblaciones marginales de la sociedad colonial (los

1945", William Roseberry et al., ed. Coffe, Society and Power in Latin America, The John Hopkins University Press. Citado por Aristides Ramos, en: Los caminos al río Magdalena. Op., cit., p.116.

71 A.G.N. Gobernaciones varias 91. F 666r. Citado por Aristides Ramos. Ibíd, p. 116. 
"arrochelados" que además de indios bravos y esclavos fugitivos, incluían toda la gama de mestizos, zambos y mulatos, así como colonos pobres venidos ilegalmente, hechiceras hierbateras, desertores, vagabundos e inclusive leprosos), como también para el conjunto de actividades ilegales asociadas al contrabando (de esclavos, armas, ron harinas, tabaco) ${ }^{\prime \prime 72}$.

El Estado se vio en la incapacidad de gobernar las vastas regiones existentes, lo que puede considerarse por los estudiosos como una herencia colonial. Al partir de la promulgación de la Constitución de 1863 se permite la introducción de comunidades religiosas para iniciar campañas de evangelización y adoctrinamiento, lo que se conoce comúnmente como misiones, las que tuvieron mayor despliegue en los antiguos territorios nacionales. Los espacios de miedo ajenos al control estatal, cobran especial significación frente a la colonización, no solo de lo simbólico sino de lo social y corporal, los que justamente deben ser dominados y domesticados mediante prácticas específicas.

Siguiendo esta lógica, el camino del Quindío fue construido merced a la mano de obra de vagos y vagas, de conformidad con la normatividad existente en materia de apertura de caminos, a saber: las disposiciones de la Ley 6 de abril de 1833, del artículo 3 de la Ley 14 de junio de 1842 y el Decreto de 31 de marzo de 1843. La Recopilación Granadina y Ordenanzas municipales contemplaron también las penas infringidas a los vagos. En Colombia, es significativo el ejercicio del poder que se ejerció contra estos, como lo refleja un decreto sancionado por el presidente Pedro Alcántara Herrán el 31 de marzo de 1830, relacionado con el concierto de vagos des-

SERJE, Margarita. El revés de la nación. Territorios salvajes, fronteras y tierras de nadie. Bogotá: Uniandes-Ceso, 2005 , p. 4. La formación interdisciplinar de esta autora, arquitecta, geógrafa y doctorada en antropología social, le ha permitido hacer una aproximación histórico-geográfica de la nación colombiana, haciendo énfasis en la producción de un contexto situacional que permita entender los códigos ocultos que subyacen, cuando se trata de interpretar el proceso de configuración de un proyecto nacional. De ahí la importancia que señala la autora en caracterizar aquel conjunto de políticas y dinámicas que han hecho posible la incorporación de sus habitantes al Estado Nacional. tinados a trabajar en el camino del Quindío, donde autorizaba el ser conminados en establecimientos públicos y destinados a conformar el núcleo poblacional de las aldeas nacientes. Otro documento contemplaba los medios coercitivos que podían usarse para obligar a los vagos a trabajar y mantenerlos sujetos, "todo con arreglo a los artículos 3 y 4 de la ley 14 de junio de 1842". Dos años después (1844) el mismo presidente sancionaba una ley que autorizaba al poder ejecutivo "trasladar de Chagras a la ciudad de Panamá, o alguna de las islas del pacífico adyacente a las de las provincias del istmo, el establecimiento de trabajos forzados que existe en el primero de estos lugares"73.

Las leyes contra la vagancia eran expedidas por el Gobierno Nacional, las Cámaras de Provincia y las Municipalidades mediante Ordenanzas, además de las Ordenanzas de Policía de las Cámaras Provinciales. Aparte de estos organismos lo estipulaba la ley $3^{\circ}$, parte $3^{a}$, tratado $1^{\circ}$ de la Recopilación Granadina, en donde se le otorgaban atributos a los jefes políticos y alcaldes, como la declaratoria en $1^{\mathrm{a}}$ instancia en calidad de vagos a los individuos comprendidos en los casos del artículo $4^{\circ}$ de la ley $9^{a}$, parte $3^{a}$, tratado $2^{\circ}$ de la misma Recopilación.

"Esta disposición -señalaba un informe de la Gobernación de la Provincia de Buenaventura a la Cámara Provincial el 15 de septiembre de 1845- está causando efectos muy saludables porque se hace

3 Decreto 16 de abril de 1844. Sobre traslación del establecimiento de trabajos forzados de Chagras a Panamá. "El senado y la Cámara de Representantes de la Nueva Granada, reunidos en el Congreso decretan:

Artículo único. El poder ejecutivo podrá trasladar de Chagras a la ciudad de Panamá o a alguna de las islas del Pacífico adyacentes a las de las provincias del istmo, el establecimiento de trabajos forzados que existe en el primero de estos lugares". Bogotá, 11 de abril de 1844. Pedro Alcántara Herrán. Codificación Nacional. Año de 1844. 
hasta ahora el debido y moderado uso de estas facultades, y concibo esperanza fundada de extirpar en la provincia una plaga social como la vagancia, funesta para la moral, para el orden y para la prosperidad pública"74.

Esta normatividad junto con el Decreto 23 de abril de 1849, sancionado por el Congreso de la República durante el gobierno del General José Hilario López (1849-1853) estimuló la colonización de las vertientes de las comarcas vírgenes del sur al suroccidente de Antioquia, lo que se tradujo en uno de los flujos migratorios más importantes del siglo XIX, tanto que algunos historiadores lo consideran como el más grande después de la conquista del oeste americano. Muchas fueron las poblaciones que se fundaron en el término de unos pocos años en los actuales departamentos de Quindío, Risaralda, Valle y El Tolima. El camino del Quindío representa un hecho notorio en su proceso de construcción, al igual que las nacientes aldeas. Sobre este particular, existe un comunicado emitido el 9 de marzo de 1844, en donde el gobernador de la provincia de Mariquita celebra la apertura del camino del Quindío, utilizando para ello mano de obra vaga, "lo que no ha sido gravoso a la empresa, logrando al mismo tiempo la corrección de varios individuos"75. De otra parte, un informe de la jefatura política del cantón de Cali (julio 9 de 1845) da cuenta de la remisión de dos mujeres prostitutas y vagabundas a la nueva población del Quindío, aunque no hace explícita a cuál aldea se refiere.

"Se ha perseguido la vagancia y desmoralización con eficacia y energía, destinando a los reos de este delito, ya al ejército permanente, ya a la nueva población del Quindío según las circunstancias de los penados. A esta última pena han sido también condenadas dos mujeres prostitutas y vagabundas, siendo de esperarse que con estos ejemplares se

$74 \quad$ A.G.N. Sección: República. Fondo: Gobernaciones varias. Tomo: 103. Folio: 596-610.

75 A.G.N. Sección: República. Fondo: Gobernaciones varias. Tomo: 116. Folio: 517. refrene un poco la desmoralización y la vagancia que por desgracia va cundiendo en este país"76.

La legislación sobre vagos es explícita al contemplar a la población masculina dentro de estos; sin embargo este fue un problema en el que también fueron incluidas mujeres en menor medida, como lo resalta un comunicado emanado de la gobernación de la provincia de Neiva, el 26 de mayo de 1846, en donde se reclaman medidas para destinar "en la casa de reclusión de Guaduas las vagas de esta provincia, haciendo los gastos del tesoro nacional. Firma Uldarico Leiva". En otro de los apartes se expresaba lo siguiente:

"Ruego por tanto a Vuestra Señoría se digne resolver lo conveniente, y tener presente que lo que la Gobernación desea es hacer entender siquiera a esta clase de vagos que puede castigarse, ofreciendo la Gobernación que se adoptaran los medios necesarios para que no vayan sino personas que ganen la subsistencia y que lejos de servir de carga al establecimiento se proporcionen ganancias para su salida y para satisfacer los costos de conducción"77.

Otro documento hace referencia a conducciones de vagos destinados a poblar las nuevas fundaciones como lo ratifica una petición en que se solicita resolver de qué fondos se deducen los gastos de conducción de vagos de la Gobernación de Neiva a la nueva población de Valdecina, ubicada en las montañas del Quindío. En respuesta a la misma, ante la escasez de las rentas provinciales, el Despacho de Relaciones Exteriores en fecha 14 de septiembre de 1846 fijó lo siguiente:

"Los vagos sentenciados a formar nuevas poblaciones, pueden ser auxiliados para su establecimiento y subsistencia por el tesoro nacional, según el artículo $4^{\circ}$ Ley $3^{\text {a }}$ parte $3^{\text {a }}$ tratado $1^{\circ}$ Recopilación Granadina, página 82. Para esto deberá sujetarse

76 A.G.N. Sección: República. Fondo: Gobernaciones varias Tomo: 103. Folio: 448.

77 A.G.N. Sección: República. Fondo: Gobernaciones varias. Tomo: 117. Folio: 746. 
a las reglas establecidas respecto de los reos que se dirijan al lugar de sus condenas. Para obviar las dificultades que se presentan al Gobernador agréguesele que usando de la autorización que le concede el artículo $2^{\circ}$ de la Ley $3^{a}$ parte $3^{\text {a }}$ tratado $1^{\circ}$ Recopilación Granadina, página 81, conmute cuando así sea justo y esté en sus facultades, la pena en la de servicio en el ejército o en la de concierto a trabajar en el Quindío, teniéndose presente con los vagos que se destinen allí, las disposiciones del decreto de 31 de marzo de 1843"78.

Como se señaló anteriormente, una buena cantidad de vagos de ambos géneros fue conducida a las nacientes poblaciones y el camino del Quindío, en otras situaciones, dependiendo de las necesidades existentes, fueron enviados a varios sitios, entre ellos al Batallón Mutis $N^{\circ} 2$, como lo refleja un documento emitido el 14 de julio de 1845, donde fueron remitidos "con sus correspondientes filiaciones a los vagos Santos Jamaica, Lorenzo Ladino, Indalecio Socha, José Ricardo Saín, Francisco Zamora, Clemente Córdova y José María Espinosa", provenientes del Cantón de Zipaquirá"79. Otro de los remitidos el 16 de julio de 1845 al Batallón Mutis fue Joaquín Posada, acusado de ser vago, con el agravante además de maltratar a su mujer Gregoria Corpus, quien se quejó de su marido "por haberla estropeado malamente, y manifestando que este lo tiene de costumbre en términos de tirarla a matar; como también que es un mozo sumamente abandonado y vagabundo que en nada le suministra para su manutención y vestuario, ni menos se le conoce oficio alguno ni aplicación al trabajo"80.

$78 \quad$ A.G.N. Sección: República. Fondo: Gobernaciones varias. Tomo: 118. Folio: 151.

79 A.G.N. Sección: República. Fondo: Gobernaciones varias. Tomo: 103. Folio: 52.

$80 \quad$ Uno de los testigos de actuación ratifica lo anterior: "Que no le conoce huerta ni sembradura alguna ni menos de jornalero; por lo que manifiesta ser un hombre vago y lo poco que la mujer coge de arrendamientos de las estancias que le dejo su primer marido por ser indio, se lo quita y no le permite vestirse por malbaratar todo, que es cuanto sabe y puede decir en fuerza del juramento que ha prestado, y leída que le fue su declaración se afirma y ratifica y ruega a uno de los testigos firme por él por no saberlo hacer, en Zipacón a 28 de abril de 1845". A.G.N.
La provincia de El Socorro presenta un caso similar, justo allí se "estableció un presidio rural para emplear a los reclusos en los trabajos del camino, aportando los contratistas el alimento para los presidiarios como también medio real para su vestuario y demás costos. La construcción del camino se verificó en los términos propuestos y el gran esfuerzo en la primera mitad del siglo XIX se dirigió a su poblamiento"81. Otra publicación oficial, describía cómo era percibido otro de los flagelos que las autoridades estaban dispuestas a corregir: "La vagancia está muy

Otro de los remitidos el 16 de julio de 1845 al Batallón Mutis fue Joaquín Posada, acusado de ser vago,

con el agravante además de maltratar

a su mujer Gregoria Corpus, quien se quejó

de su marido "por

haberla estropeado malamente, y

manifestando que este lo tiene de costumbre en términos de tirarla a

matar extinguida en este período, merced a la actitud del actual jefe municipal, y a no ser por la intransigencia de cierto partido político y la poca prudencia de algunos empleados, este pueblo progresaría con mucha rapidez y sería modelo por la moralidad de sus costumbres y la laboriosidad de sus habitantes" 82 .

Las medidas de control social contra la vagancia estuvieron orientadas a resocializar a los individuos mediante el trabajo. Con esta medida, las zonas de frontera como la población de El Socorro, tuvieron un desarrollo económico sostenible merced al concertaje de vagos. Aristides Ramos, señala cómo en 1838 el gobernador de El Socorro solicitaba a la Cámara Provincial, una

"ley de policía bien clara y detallada, una ley que amplíe la facultad de los jefes políticos y arregle

Sección: República. Fondo: Gobernaciones varias. Tomo: 103. Folios 75-77.

81 RAMOS PEÑUELA, Aristides. Los caminos al río Magdalena. Op., cit., p. 138.

82 Ibíd, p. 203. 
su modo de proceder con brevedad, sin dejar de sujetarlos a la más estricta responsabilidad, una ley en fin que destine a los cantones poco poblados o a las nuevas poblaciones a los hombres conocidamente vagos, a los viciosos consuetudinarios, a los hijos que no puedan ser sujetados por la autoridad paterna, a los tramposos y a las públicas prostitutas que arruinan la salud y escandalizan al público. Los caminos del Chucurí y del Opón reclaman pobladores, a ellos pueden enviarse los hombres que se han perdido en la sociedad para que convertidos en laboriosos ciudadanos en medio de fértiles e incultos campos y sin motivo alguno de disipación se dediquen al trabajo, olviden los malos hábitos, hagan su propia fortuna, aumenten la población y contribuyan a la prosperidad de la nación" ${ }^{\prime \prime 3}$.

La frontera de colonización en la región del Carare, y junto a ella las nacientes poblaciones se vieron fortalecidas mediante el concertaje de vagos. El poblamiento de las fronteras permitió un intercambio comercial con otras regiones. "Es un caso histórico más de asociación entre la frontera y las medidas de control social. Poblar la frontera, considerada espacio vital para unas economías centrales, es el factor común"84. Las autoridades locales como alcaldes y corregidores, también contribuyeron a crear mediante mecanismos coercitivos, la necesidad de salvaguardar la moral y sanas costumbres. En el juicio adelantado por vagancia contra Marco Aurelio Gámez, por pernicioso y vago, la Prefectura de la Provincia de Cúcuta considera lo siguiente:

"10. Que es necesario dictar medidas rigurosas con el objeto de alejar de las poblaciones los elementos perniciosos y perturbadores del sosiego público;

$2^{\circ}$. Que el Gobierno tiene grandísimo interés en acabar por completo con estos elementos, para lo cual ha expedido la importante Ley de Alta Policía Nacional sobre vagancia; y teniendo en cuenta que todas las declaraciones contenidas en el presente expediente están acordes en calificar a Marco Aurelio Gámez como vago y de conducta perniciosa,

\footnotetext{
83 Ibíd, p. 143.

84 Ibíd, p. 144
}

concepto emitido también por la Alcaldía de esta ciudad y por la opinión pública de la localidad.

Resuelve:

Confínase a Marco Aurelio Gámez a la Colonia Penal de Villavicencio por el término de seis meses.

Remítasele junto con el expediente respectivo al Señor Gobernador para que él disponga la manera de conducirlo á su destino.

Sométase esta resolución á la censura del Señor Gobernador.

\section{Alfredo Fernández R. El Secretario"85.}

Una de las voces más autorizadas para cumplir con esta misión moralizante lo constituyó la iglesia. Las palabras del presidente del cabildo de Jericó, son dicientes: "El pueblo ha ganado en pobladores pero ha perdido inmensurablemente en moralidad. Los vagos, los ebrios, los tahúres y los matasiete pululan en las calles, en la plaza y en los garitos" 86 . Las medidas de policía estuvieron orientadas además de cumplir una función moralizante, a promover el sentido de convivencia en espacios estéticamente visuales, así como el buen uso de los pesos y medidas, ajustadas a las leyes, como las adoptadas por Rufino Cuervo cuando era gobernador de la provincia de Santa Fe; así fue como dictó en 1831 los primeros decretos contra la vagancia, la prostitución y los juegos. Con este propósito fundó la Casa de Refugio según sus palabras "...para el choque de la holgazanería, mendicidad y ociosidad"87.

El control fue ejercido no sólo contra poblaciones que representaban un estigma social, como los la-

85 A.G.N. Sección: Archivo Anexo II. Fondo: Ministerio de Guerra. Serie: Asuntos Judiciales, Procesos. Caja: 2. Carpeta: 4. Año 1907, Folios: 12-16

86 Archivo Histórico de Jericó. (A.H.J.) Libro 6, año 1871, legajo 8, folio 10. Ídem.

87 Documentos oficiales para la historia i la estadística de la Nueva Granada. Bogotá: imprenta de J. A Cualla, 1843. p. 3. Codificación Nacional, T. VI., pp. 28-30. Citado por RAMOS, Aristides en: Los Caminos al río Magdalena. Op., cit., p. 76. 
zarinos, vagos, borrachos, tahúres y población desempleada, sino contra aquellos que potencialmente pudieran representar un peligro social como los forasteros ${ }^{88}$. En Caramanta (Antioquia) la educación impartida por el cura del pueblo surtió los efectos esperados, como lo expresa un documento oficial de la región: "Allí no hubo necesidad de dictar disposición alguna en el ramo de policía... debido a que el presbítero Juan N. Cadavid ha moralizado mui notablemente a las masas populares en términos de que no se da lugar por los vecinos del distrito a que se les corrija o castigue conforme a la ley de policía"89. También en la población antioqueña de Valparaíso, se ordenó "que todo individuo forastero" que permaneciera por más de tres días en el distrito, diera cuenta del objeto de su residencia90.

Igualmente al Estado se le asignó la función de promover los valores morales y éticos considerados básicos para el desarrollo económico y social como fueron el amor al trabajo, la condena a la ociosidad y su resocialización; en el cumplimiento de estas funciones, se vieron ante la dificultad para tipificar comportamientos delictuales, ante la ausencia de un término clarificador, pues a menudo se asociaba el ejercicio de la vagancia a expresiones que dieron lugar a ambigüedades. El gobernador de Antioquia, Cayetano Buelta Lorenzana (1776-1782) estableció una distinción entre vagabundos, falsos y verdaderos pobres y ociosos, para facilitar la acción de la justicia. En 1777 durante su administración como gobernador, expresó en un documento para una enmienda de ley lo siguiente:

88 El caso antioqueño es bien significativo. En Valparaíso se ordenó "que todo individuo forastero" que permaneciera por más de tres días en el distrito, diera cuenta del objeto de su residencia. Juan Carlos Vélez Rendón, en: Los pueblos allende el río Cauca. Op., cit., p. 197.

89 Boletín Oficial No. 276. Medellín, 11 de mayo de 1868, p. 149. Citado por VÉLEZ RENDÓN, Juan Carlos. Op., cit,. p. 203. La población de Andes, en Antioquia representa un caso típico de control social local, pues no solo se dictaron medidas contra los borrachos, sino que además se creó la "sociedad de amigos de la moral y de la educación".

90 VÉLEZ RENDÓN, Juan Carlos. Los pueblos allende el río Cauca. Op., cit., p. 197. "y para que no se ofrezca duda sobre la distinción, que hay de la clase de ociosos a la que se refiere la presente, que ociosos son aquellos de residencia fija en un pueblo, sitio o estancia, que no se sujetan al trabajo diario y no siembran lo proporcionado para su manutención y la de su familia, pues no les exime de la clase de ociosos una corta sementera, ni algunos días de trabajo, estando la mayor parte del año sin ejercitarse en el cultivo del campo. Vagos son aquellos que no tienen domicilio cierto, $y$ andan de una parte a otra sin legítimo motivo, $y$ para incurrir en la clase de vago, es bastante prueba, el que esté en cualquiera población un mes, sin destino formal ni solicitarlo, y teniendo presente el daño que en castigo de la culpa de nuestros primeros padres les impuso el mismo Dios la pena de que se mantuviesen con el sudor de su rostro, reputa por ladrones de la República a todos los ociosos y vagos que en contravención a este divino precepto, se mantienen con el sudor y el trabajo de su prójimo, en cuyo concepto deben ser como perniciosos y perjudiciales, expelidos y arrojados de la república, y será muy culpable cualquiera que los auxiliare, aunque sea con el pretexto de piedad, y limosna, pues esta se debe ejecutar con los pobres, viejos, enfermos, tullidos, y otros, que con legítimo impedimento no pueden trabajar; pero no con una clase de gente tan perniciosa y nociva"91.

Estas medidas de control social tenían la intención de corregir las desviaciones de los ociosos, promover valores éticos acerca de la importancia y la necesidad del trabajo. En otras situaciones, a los vagos les conmutaban la pena en las colonias penitenciarias, a cambio de prestar sus servicios en el ejército ${ }^{92}$ como lo refleja el caso siguiente: El Alcalde de Tocancipá, en junio de 1905 remitió a Abraham Cuervo, "individuo de mala conducta, vago y ratero" para ser conducido

$1 \quad$ A.G.N. Sección: Colonia. Fondo: Real Audiencia - Cundinamarca. Curas y obispos, Tomo 48. № 105, años 1776 1778. Fls. $229-225$ v. Cayetano Buelta Lorenzana, Gobernador de Antioquia, su decreto sobre respeto a las cosas religiosas de observancia de la moral y otros asuntos de buen gobierno, 1777 .

92 Diligencias contra Abraham Cuervo, por vago. A.G.N Sección: Archivo, Anexo II. Fondo: Ministerio de Guerra. Serie: Asuntos Judiciales, Procesos. Caja 3. Carpeta 1. Año 1905. Folios 7-10. 
a una colonia penitenciaria, pero finalmente la Prefectura conceptuó que era mejor enviarlo al ejército y prestara sus servicios como zapador.

Otro de los tantos casos adelantados por vagancia fue el que tuvo lugar en Medellín el día 6 de mayo de 1908, cuando fueron retenidas veintidós personas, por resolución de la gobernación de Antioquia y el Ministerio de Guerra, quienes fueron condenados a seis meses de confinamiento en la Colonia Penal del Magdalena "en calidad de colonos fundadores"93. Después de cumplir con el tiempo de permanencia en la colonia penal, fueron puestos en libertad en Aracataca, Magdalena, en el mes de mayo del mismo año.

El camino del Quindío al igual que las nacientes fundaciones de la región y el Carare, surgieron como contribución de mano de obra de vagos y vagas como lo reflejan los documentos referenciados; si bien no fueron los únicos, sí fueron los más connotados, pues en una época más reciente (1924) cuando ya no se hablaba de caminos sino de carreteras, fueron unidas las poblaciones de Cúcuta y Pamplona mediante esta modalidad. La Ordenanza $N^{\circ} 27$ del Código de Policía del Departamento de Norte de Santander en 1924 incluyó a los vagos y vagas como mano de obra fuerza en la apertura de la carretera de Cúcuta a Pamplona, en los siguientes términos:

"Artículo $1^{\circ}$. Las obras públicas a que deben ser condenados los vagos según el artículo 127 de Ordenanza número 54 de 1912, serán las de la Carretera de Cúcuta a Pamplona, mientras haya trabajo en aquellas obras o las que el gobierno estime conveniente. Exceptúense de esta disposición los

93 Los condenados responden a los siguientes nombres: "Antonio Restrepo, Francisco Restrepo, Celestino Isaza, Francisco Naranjo, Dionisio Uribe, Manuel A. Toro, Jesús A. López, Alejandro Ospina, Gabriel Castaño, Joaquín Morales, Antonio J. Villa, Ricardo Mejía, Julio Montoya, Manuel A. Palacio, Custodio Velásquez, Luciano Grisales, J. David López, J. María Molina, Marco F. Escobar, Joaquín Brano C., Rigoberto Hoyos y Benjamín Velásquez". A.G.N. Sección: Archivo Anexo II. Fondo: Ministerio de Guerra. Serie: Asuntos Judiciales, Procesos. Caja: 1. Carpeta: 1. Años 1895-1908, Folios 47-57. de la Provincia de Ocaña, quienes trabajaran en las obras públicas de ésta.

Artículo $2^{\circ}$. Todas las autoridades municipales que de acuerdo con lo estatuido en el capítulo $X$ de la ordenanza 54 de 1912 tengan que conocer de la declaratoria de vagos en alguna o algunas personas, remitirán a ésta o éstas, condenadas que fueren, si estuvieren comprendidas entre las destinadas a trabajos públicos, por conducto de la primera autoridad de la respectiva Provincia, a los trabajos establecidos, en la Carretera de Cúcuta a Pamplona y a los demás que el Gobierno designe. Los gastos de conducción y alimentación serán costeados por el Departamento".

\subsection{El pensamiento liberal y su oposición a las leyes de vagancia}

Suele entenderse el liberalismo como una doctrina librecambista por un lado, y filosófico por otro, componentes que estuvieron presentes en la mayoría de constituciones políticas de occidente, promulgadas después de la Revolución Francesa de 1789. Fue también el resultado de varios elementos, entre ellos el ascenso del antropocentrismo renacentista, la influencia que ejerció el protestantismo luterano, el racionalismo y el utilitarismo, además de una economía artesanal bastante limitada, lo suficiente para no generar ningún excedente en la producción. El liberalismo irrumpe en la historia como un modelo de interpretación social, edificado sobre las ruinas medievales sobre las que se erige un nuevo orden político y económico, sustentado en el individualismo y las libertades básicas. Así, surge una nueva filosofía que propende a un desarrollo de los seres humanos en función de proyectos sociales y políticos, que promueven el desarrollo de las libertades individuales y la no injerencia del Estado en la esfera personal.

En Colombia, la recepción de las ideas liberales a mediados del siglo XIX en la que coincidieron por demás con la élite conservadora, residió en la necesidad de impulsar el desarrollo económico del país mediante la participación activa en el mercado mundial. En esta medida, el país debería asumir una postura exportadora de materias primas, e impor- 
tadora de productos que escaseaban en el mercado nacional. La recepción del liberalismo económico se tradujo en el librecambio, manifestado en diversos órdenes como el desmonte de los impuestos a las mercancías importadas y la eliminación del monopolio del tabaco, entre otros aspectos. José Hilario López, consecuente con las ideas librecambistas, ejerció durante su presidencia (1849-1853) reformas liberales como la eliminación de la esclavitud, la pena de muerte, la expropiación de los bienes eclesiásticos, la libertad de prensa, así como la escisión entre iglesia y Estado, entre otros aspectos.

Durante el siglo XIX, cuando el pensamiento liberal conquista ciertos espacios en el ámbito social y se promueve la idea del libre mercado, donde las leyes más conocidas como concertaje de vagos y penas por vagancia fueron perdiendo vigencia, hasta ser derogadas finalmente por la élite liberal hacia $1851^{94}$. Estas disposiciones despertaron el repudio de intelectuales que como Manuel Ancízar las vieron contrarias no solo al pensamiento liberal, sino también a la moralidad propia que los gobernantes deberían seguir. En este sentido Ancízar expresó lo siguiente:

"Varias veces se ha intentado someterlas a una policía perseguidora, y por decenas se las ha enviado a morir de miseria y fiebres a las selvas de Chucurí, sin que por esto hubiesen mejorado las cosas. Matar no es moralizar; además de que no concibo con qué derecho pueda una sociedad cualquiera castigar los desórdenes de que ella misma por su indiferencia causante. Si los vecinos pudientes del Socorro hubiesen tomado interés en la educación industrial de las mujeres pobres, abriéndoles talleres de oficios y enseñándolas el camino de la vida honrada, entonces tendrían derecho para pedir a las autoridades la persecución de las holgazanas y viciosas, como una protección a las buenas costumbres de la porción sana del pueblo, y como un remedio que atajara la propagación del mal hasta sus propias familias; de otra manera, el castigo es iniquidad, y las persecuciones de la policía, perma-

94 Gaceta Oficial. Bogotá, sábado 3 de mayo de 1851, No. 1219. neciendo vigente la causa de las acciones punibles, llegarían a convertirse en única y constante regla de gobierno, es decir, en la más intolerable de las tiranías"95.

De conformidad con lo anterior, una postura bastante sugestiva por cierto, lo constituye un documento proveniente del Gobierno Municipal de la Provincia del Chocó (Quibdó) fechado el 14 de julio de 1855, en donde una resolución del funcionario Nicomedes Conto, considera no vigentes las leyes contra la vagancia, en especial el título $1^{\circ}$ de la Ley $3^{a}$ parte $3^{a}$ tratado $1^{\circ}$ de la Recopilación Granadina, como tampoco la Ley $9^{a}$ parte $3^{a}$ tratado $2^{\circ}$ de la misma, sobre vagos, atendiendo a las siguientes consideraciones:

"10. Que cuando el inciso $1^{\circ}$ del artículo $5^{\circ}$ de la Constitución de la República garantiza la libertad individual, lo hace de una manera general, admitiendo las restricciones de las leyes.

$2^{\circ}$. Que el inciso $4^{\circ}$ del mismo artículo garantiza la libertad de industria y de trabajo, y que la vagancia lejos de ser una industria o trabajo, es la carencia de ella.

$3^{\circ}$. Que no obstante que el inciso $2^{\circ}$ del citado artículo Constitucional sanciona la seguridad personal, consistente en no ser preciso detenido, etc., sino por motivo puramente criminal conforme a las leyes, las que persiguen la vagancia no chocan con esta garantía, porque crimen es la violación de las leyes, y prohibiéndose por estas la vagancia, comete infracción todo el que a ella se dedique, consideraciones que tuvo presente el Poder Ejecutivo al dictar su resolución de 30 de agosto de 1853 (Gaceta oficial $n^{\circ}$. 1594).

$4^{\circ}$. Que en la única parte que las citadas leyes se encuentran en pugna con la Constitución es en cuanto establecen que la pena de vagancia, que puede exceder de dos años de privación de libertad, se aplique por los funcionarios del orden político, supuesto que el inciso 11 del mismo artículo $5^{\circ}$

5 RAMOS PEÑUELA, Aristides. Los caminos al río Magdalena. Op., cit., p. 146. 
de la Constitución de la República requiere el juicio por jurado en todos los casos en quien se proceda por delito o crimen que merezca pena corporal o la pérdida de la libertad del individuo por más de dos años; por cuya disposición han quedado los funcionarios de que habla el artículo $1^{\circ}$ de la Recopilación Granadina sin la facultad de imponer tal pena, debiendo corresponder al jurado.

$5^{\circ}$. Que las leyes que castigan la vagancia deben tener su ejecución en todo lo que no son contrarias a las legislaturas provinciales, no se reformen en uso de la facultad que les confiere el inciso $5^{\circ}$ del artículo $1^{\circ}$ de la Ley 17 de abril último para organizar la policía en todos sus ramos, a cuya materia pertenece la de vagancia.

\section{Se resuelve}

El Poder Ejecutivo es de concepto que se hallan vigentes el título $1^{\circ}$ de la Ley $3^{a}$ parte $3^{a}$ tratado $1^{\circ}$ y la $9^{a}$ y otro tratado $2^{\circ}$ de la Recopilación Granadina, con excepción de la parte que atribuye a los funcionarios del orden político, la facultad de imponer la pena, cuando esta sea por más de dos años de privación de libertad.

$$
\text { Comuníquese y publíquese" }{ }^{\prime \prime 6} \text {. }
$$

Posteriormente, en un comunicado aclaratorio al alcalde de Nóvita, en donde se solicita aclarar sobre si están vigentes las leyes contra la vagancia, ratifica esta decisión con argumentos más plausibles,

\section{“Considerando:}

$1^{\circ}$. Que la República garantiza a todos los granadinos "la libertad individual, que no reconoce otros límites que la libertad de otro individuo, según la leyes" (Constitución Nacional, artículo $5^{\circ}$ inciso $\left.1^{\circ}\right)$; y en tal virtud cada uno es libre para dejar de trabajar, puesto que su inacción no ataca la libertad de nadie.

$96 \quad$ A.G.N. Sección: República. Fondo: Gobernaciones Varias. Tomo: 191. Caja: 1. Carpeta: 2. Folio: 405. $2^{\circ}$. Que el inciso $4^{\circ}$ del mismo artículo de la Constitución garantiza también "la libertad de industria y de trabajo"; por lo cual puede tenerse la ocupación que se quiera, con las restricciones de las leyes, pero no ser obligado a ejercer un oficio cualquiera.

$3^{\circ}$. Que si un vago, por consecuencia de su ociosidad o falta de recursos, ejecuta un hecho punible, es castigado conforme a la ley penal común, por el hecho positivo criminoso, y no por la vagancia o la no ocupación. Y

$4^{\circ}$. Que las leyes contra la vagancia son contrarias a las disposiciones citadas y han quedado virtualmente derogadas por el artículo 58 de la misma Constitución;

\section{Resuelve:}

La Gobernación es de concepto, que no está vigente el título $1^{\circ}$ de la Ley $3^{a}$ parte $3^{a}$ tratado $1^{\circ}$ de la Recopilación Granadina ni la Ley $9^{a}$ parte $3^{a}$ tratado $2^{\circ}$ de la misma Recopilación.

Dese cuenta al Poder Ejecutivo para los efectos consiguientes, publicándose el resultado oportunamente.

Nicomedes Conto. El Secretario, Régulo lbáñez" ${ }^{\prime \prime 7}$.

En síntesis, el pensamiento liberal contribuyó a crear un ambiente de fraternidad en torno a proyectos libertarios como la liberación de la esclavitud, donde se esgrimieron todo tipo de argumentos altruistas y ennoblecedores, en la misma proporción que perdían vigencia las leyes relacionadas con el concertaje de vagos, más no por ello contra la vagancia en sentido genérico, pues como se resalta en el siguiente acápite, los Códigos de Policía asocian la vagancia a delitos como la ratería, donde el ser vago sigue siendo un hecho punible.

$7 \quad$ A.G.N. Sección: República. Fondo: Gobernaciones Varias. Tomo: 191. Caja: 1. Carpeta: 2. Folio: 406. 


\subsection{Reglamento de Policía Nacional sobre va- gancia y ratería}

La Policía como institución creada para proteger a los ciudadanos, requiere de unos mecanismos como Ordenanzas, Decretos, Leyes y Resoluciones de carácter nacional para hacer posible la conservación del orden público y prevenir acciones penales. Con la creación de esta institución el 5 de noviembre de 1891 siendo presidente encargado el doctor Carlos Holguín, se elimina la Policía Departamental, municipal y los serenos que velaban por el bien público; en lo sucesivo, algunos Códigos de Policía Departamental incorporaron la normativa de años anteriores -salvo pequeñas modificaciones-con lo que parece indicar que el modelo a seguir fue el decreto 1863 de noviembre 8 de 1926, por el cual se fija el Reglamento de Policía Nacional sobre vagancia y ratería, en donde se contempla lo siguiente:

\section{"Artículo 1. Son vagos:}

1. Los que, sin tener oficio, capital o renta no comprueben medios lícitos y honestos de subsistencia. $2^{\circ}$. Los individuos que sufran cuatro o más condenas de policía en un semestre.

$3^{\circ}$. Los menores de edad que causen frecuentes escándalos por su insubordinación a la autoridad de las personas de quienes dependan, o que observen reconocidas malas costumbres, o que sean hallados en casas de lenocinio por tres veces o más en un trimestre, o en casas de juegos permitidos por más de cinco veces por trimestre".

También incorpora esta norma en lo relacionado con los vagos, delitos conexos como los ebrios consuetudinarios, los que se hallaren practicando juegos prohibidos, los reincidentes, rameras, mendigos y los que andan de pueblo en pueblo sin ejercer una industria $u$ oficio que les proporcione honradamente la subsistencia. Posteriormente, la Policía del Departamento del Atlántico expide la ordenanza $\mathrm{N}^{\circ} 72$ de 6 de octubre de 1931, que consagra en materia de vagancia lo establecido en el Código de 1926, por lo que al parecer, este fue el modelo a seguir. Del mismo modo, el Código de Policía de Cundinamarca de 1942 en su sexta edición (Librería Colombiana Camacho Roldán \& Cía., Ltda. Calle 12, No. 7-50. Bo- gotá: Editorial Antena, Bogotá), consagra los artículos sobre vagancia de manera textual a lo expresado en el Código de Policía de 1939, lo que denota una continuidad normativa.

De otra parte, la Ordenanza N 56 de 1927, por la cual se expidió el Código de Policía del Departamento de Nariño, en su capítulo II, artículo 1276 referente a la vagancia, transcribe tácitamente lo anunciado en el artículo $1^{\circ}$ del Decreto 1863 de 1926, en la que fue incluida una pequeña adición ${ }^{98}$.

98 "Artículo 1277. El Alcalde del Distrito de la residencia del presunto vago, será el único empleado competente para conocer de los denuncios que se presenten sobre esa clase de hechos.

Artículo 1278. Todo individuo puede denunciar como vago al que encontrare en el caso del artículo 1272

Artículo 1279. Se entiende por reincidente todo individuo que habiendo sido condenado por vagancia vuelva a delinquir dentro de cinco años posteriores a la condenación.

Artículo 1280. Cuando un individuo que va a permanecer más de tres días, sean sospechosos de vagancia, por resultar que no tiene oficio o profesión o motivo lícito para permanecer en el lugar o que su ocupación sea peligrosa para la moralidad y buenas costumbres, el Alcalde hará vigilar a tal individuo, y si resultare que es vago, instruirá el sumario correspondiente para establecer la prueba legal.

Artículo 1281. Cuando el individuo sobre quien recae sospechas fundadas de ser vago se marchare a otro Distrito distinto del en que reside, el Alcalde de éste lo hará saber así ante el del Distrito de la nueva residencia, indicándole las razones que haya para suponer vago a tal individuo y el deber de vigilarlo.

Artículo 1282. En todos los casos, si de la prueba reconocida resultare el cargo de vago, se citará al responsable con el objeto de requerirlo para que cambie sus hábitos viciosos, dictando para ello una resolución motivada.

Artículo 1283. Si pasados dos meses, el responsable continuare en sus hábitos viciosos, se dictará nuevo requerimiento.

Artículo 1284 . Si el requerido no cambiare su modo de vivir después del segundo requerimiento en el curso de dos meses, a contar de la fecha de esta providencia, se le impondrá una pena de seis meses a un año de trabajo en obras públicas.

Artículo 1285. Si el condenado por vagancia reincidiere, se le impondrá la pena de un año de relegación a una colonia penal o agrícola de las que funde el Gobierno Nacional, por la primera reincidencia; a dos años si reincidiere por segunda vez, y a tres, si llegare a reincidir por tercera vez.

Artículo 1286. Si el Gobierno Nacional no fundare las colonias penales agrícolas, se castigará a los reincidentes con trabajo en obras públicas, por igual tiempo al señalado para la relegación a la colonia penal y agrícola. 
Esta continuidad se expresa también en el Código de Policía de Cundinamarca y doctrinas interpretativas de 1933 en su cuarta edición, y en lo concerniente a vagos son idénticas a los de 1926, salvo una nota aclaratoria que explicita lo siguiente:

"Incluimos a continuación las disposiciones de Policía Nacional sobre "vagancia y ratería", por ser de aplicación constante por las autoridades departamentales y estimarse que son las vigentes hoy sobre el particular; pero como las Ordenanzas sobre la materia no han sido derogadas ni reformadas hasta la fecha, hemos considerado que deben continuar figurando en el Código mientras la Asamblea Departamental no disponga otra cosa"99.

Hasta aquí, la normativa más importante en lo relacionado con la institución policial, en la que puede advertirse que la norma directriz fue la expresada en el Decreto 1863 de noviembre 28 de 1926. Posteriormente, la Ley 48 de 1936 (marzo 13) o disposiciones sobre represión de estados antisociales (vagos, maleantes y rateros), en su artículo $1^{\circ}$ se presume que son vagos:

a. "El que habitualmente y sin causa justificativa no ejerce ocupación u oficio lícito o tolerado, y cuyos antecedentes den fundamento para considerarlo como elemento perjudicial a la sociedad.
Artículo 1287. En el tiempo que dure la pena de los condenados por vagancia se les señalará un arte u oficio que les dé medios de subsistencia.

Artículo 1288 . Todo vago que esté sufriendo condenación, será puesto en libertad, si no ha sido reincidente, por el Alcalde Municipal, si así lo solicitare el Consejo de la vecindad del penado, mediante resolución escrita que justifique la medida, o una o más personas honorables que respondan con garantías suficientes de la conducta buena futura del reo.

Artículo 1289. El relegado que se fugare de la colonia o la abandonare antes de cumplir la condena, perderá el tiempo de relegación que hubiere satisfecho". (Gaceta Departamental. Número extraordinario. Ordenanza Número 56 de 1927 (Mayo 3). Sobre Edición Oficial. Pasto-1927. Imprenta del Departamento, pp. 311-314).

99 Código de Policía de Cundinamarca y doctrinas interpretativas de 1933. Cuarta Edición. Bogotá: Imprenta Departamental, 1933, pp. 15-116. b. El que habitualmente y sin causa justificativa se dedique a la mendicidad.

c. El que habitualmente induzca o mande a sus hijos, parientes o subordinados que sean menores de edad, a mendigar públicamente y los que, en general, se valgan de menores para el mismo fin"100.

En síntesis, en el siglo XX, la normativa que orientó las directrices sobre los vagos, lo constituye el Decreto 1863 de noviembre 28 de 1926, en donde contempla una tipología mucho más explícita, comparativamente con la anterior legislación.

\section{RESULTADOS Y CONCLUSIONES}

La genealogía foucaultiana como análisis de discursos sobre poblaciones, en este caso los vagos, sintetiza en las expresiones gubernamentalidad y de policía como técnica de gobierno. Frente a la tradición positivista de interpretar el sentido de la historia en línea ascendente y la exacerbación de la verdad como punto de llegada mediante la existencia del método científico, Foucault propone rupturas y discontinuidades para señalar cómo han devenido estas prácticas lingüísticas y su aplicación en determinados contextos. A Foucault le correspondió dar cuenta del modus operandi de estos discursos en la sociedad que le tocó vivir; su mayor legado fue quizá el haber teorizado sobre culturas subalternas que no han figurado en la historia, y ante todo centrar sus inquietudes basado en problemas, se asumen

100 BALCÁZAR PARDO, Marino. Disposiciones sobre indígenas, adjudicación de baldíos y represión de estados antisociales (vagos, maleantes y rateros). Primera edición arreglada y dirigida por Marino Balcázar Pardo, jefe de la Sección de Justicia y Minas del departamento del Cauca, 1954. Estas disposiciones expuestas en la Ley 48 de 1936 , establece en su artículo $2^{\circ}$, el que a su vez fue reformado por el artículo $2^{\circ}$ del Decreto Extraordinario 1426 de 1950, que dice: "Para establecer la presunción de que trata el artículo $1^{\circ}$ de la Ley 48 de 1936, servirán de prueba las constancias escritas, ya sean de carácter policivo o judicial, así como los certificados expedidos por los Directores de las cárceles, de lo cual aparezca que el sindicado ha sido conducido ante la autoridad por dos o más veces, como persona ociosa o perjudicial para la sociedad. Servirán también de prueba las ordinarias comunes". 
como propuestas que orientan muchas de las investigaciones en la actualidad.

En lo relacionado con la satisfacción de las necesidades básicas se presentaron dos iniciativas en la manera de concebir la pobreza: la caridad cristiana, que hacía énfasis en el sentimiento religioso basado en el principio del buen ciudadano, al considerar que un acto de piedad contribuía a satisfacer las necesidades básicas de los menesterosos; la caridad cristiana tuvo un fuerte componente religioso que buscaba el bienestar del pobre mediante la limosna, como un acto de piedad por parte del buen cristiano en busca de su salvación y amor al prójimo. El pobre era visto como un instrumento de salvación del alma a quien se le debe ayudar a cubrir sus necesidades básicas; de otra parte, la caridad ilustrada o estatal, señalaba que era una misión de Estado velar por el cumplimento de las necesidades básicas. La caridad ilustrada orientó sus acciones estatales de recolección y canalización de los fondos que se destinaron para la manutención de los llamados "vagos, malentretenidos y pobres" a través de los hospicios, donde el "pobre, el vagabundo, el niño expósito" fueron recluidos no solo para cubrir sus necesidades básicas, sino que se le ayudaba a encontrar un oficio para y dejar la holgazanería. El encierro posibilitaba la acción de la disciplina, transformándolos en cuerpos activos y productivos.

La dinámica capitalista fue entendida bajo la actitud disciplinaria de ayuda a los menesterosos, como la posibilidad de encontrar una actividad para ser útil a la sociedad. En esta medida es posible considerar que el hospicio, más que un espacio para cubrir las necesidades básicas de los menesterosos, fue un mecanismo que coadyuvó a abandonar la holgazanería. El antiguo régimen consideraba que el encierro posibilitaba la acción de la disciplina, transformándolos en cuerpos activos y productivos, como lo expresó Foucault en La verdad y las formas jurídicas.

Al tomar como referencia los aportes de este pensador francés, en el sentido de establecer una genealogía para establecer cómo han devenido esos discursos, se advierte que gubernamentalidad como lógica racional estatal, tuvo vigencia en función de la población en mención, en el sentido de considerar que cuando se tiene conocimiento de un problema social, se diseñan los mecanismos para su erradicación. Este entramado de discursos en buena medida se soporta en el ordenamiento jurídico a nivel nacional, regional y local; como puede derivarse de estas expresiones jurídicas, -de por sí bastante amplias aunque dispersas- se tuvo la intencionalidad de presentar el ámbito jurídico que corresponde a momentos geográficos y preocupaciones distintas, soportado con algunos casos particulares, donde se muestra el papel en función de lo estatal.

La exclusión social de los vagos se expresó, no tanto bajo la idea de rehabilitar, sino con el propósito de apartar lo no constructivo. La sociedad no tolera lo improductivo, criterio asociado por demás al degeneramiento moral, encarnación misma de lo aborrecible y un atentado contra las leyes de la naturaleza y la sociedad. Los vagos fueron tipificados en una variedad amplia de delitos y continuaron siéndolo en el período republicano y en buena medida durante las tres primeras décadas del siglo $X X$, donde el trabajo fue visto como una especie de ortopedia social. En efecto, puede notarse una notoria distinción entre los usos coloniales y los republicanos, donde se advierte una tipificación más clara y precisa. Con la adopción de los códigos de policía regionales, se nota que la tipificación de este delito es mucho más explícita como se advierte en los mismos; de otra parte, si existe un eje articulador, este es el Decreto 1863 de noviembre de 1926 que se convierte en el modelo a seguir, plasmado en los reglamentos departamentales.

El control del espacio ha sido una preocupación ejercida no solo física sino simbólicamente por los estados nacionales, regionales y locales, sustentados en gran medida en censos, estadística y estudios cartográficos, contribuye al diseño de políticas públicas orientadas a ejercer la inclusión social. El hecho mismo de administrar o gerenciar la existencia, constituye uno de los aspectos de lo que suele denominarse como biopolítica social. De manera similar, como sucedió con la población de vagos, tiene un fuerte desarrollo a partir de lo institucional, como se evidenció en la segunda parte de este ensayo. De otra parte, la institución eclesiástica y las 
comunidades religiosas que ingresaron al país con la complacencia de los mandatarios, contribuyeron a consolidar la idea de una moral social que orientara las actividades de los hombres hacia el trabajo como factor de desarrollo social, o lo que denominó Bordieu "violencia simbólica", es decir, la manera de imponer una nueva forma de ver las cosas a partir de una visión dominante. Una de las voces más autorizadas para cumplir con esta misión moralizante lo constituyó la iglesia.

\section{ANEXO DOCUMENTAL}

\section{DOCUMENTO No 1}

\section{(Exposición del Secretario del Interior y Relaciones Exteriores, Lino de Pombo, presentada al Congreso de 1835)}

"Todos los esfuerzos que se hagan para extirpar estos azotes de la sociedad, y para rehabilitar en ella la multitud de individuos que en calidad de vagos y de mendigos la sirven ahora de molesta carga, serán otros tantos pasos importantes en favor de la moral, de la industria y de la riqueza nacional. Al hacer honrado y laborioso, quizá contra su voluntad, a un hombre que por la desfavorable influencia de las circunstancias, por los vicios de la educación, por falta de estímulos o por natural indolencia había contraído el hábito funesto de la ociosidad, no es a él sólo a quien se beneficia; se adquiere un nuevo agente de producción, quitándolo a la depravación de costumbres; y se transforma en un buen padre de familia y en un apoyo de la libertad y desorden al que entraría en todo plan de trastorno para medrar a costa ajena, y sólo serviría para sí olvidando hasta los deberes naturales. Una buena ley de policía, bien cumplida, produciría entre otros este resultado provechoso, si su ejecución quedaba encomendada a los funcionarios del orden político; y serviría de apoyo a lo que en el mismo sentido trabajan con celoso pero poco eficaz interés las cámaras de provincia y los concejos municipales.

Actualmente los vagos calificados como tales, después de un juicio en que a la mayor parte les es fácil producir supuestas pruebas de que no lo son, o gubernativamente, van destinados al ser- vicio en el Ejército o en la Marina, si el juez o la autoridad política en su caso, cuidan de perseguirlos; empero es tan reducido el personal de nuestra marina y de nuestro Ejército, en donde no puede recibirse a los vagos sino en cierta proporción prudente y cuando sea físicamente aptos para el servicio, que si se persiguiese a éstos con la eficacia debida no habría cabida para ellos en ninguna de las dos armas; y por otra parte, siendo de una misma clase la pena o corrección para todos, necesariamente ha de ser desigual e injusta con frecuencia en la práctica. Parece que deberían establecerse ciertas graduaciones en esa pena o corrección, dejando hasta cierto punto discrecional su aplicación a las respectivas autoridades políticas locales; y que el aprendizaje forzado de algún oficio, el oficio doméstico de la misma naturaleza, el trabajo a ración en las obras públicas de las provincias o cantones, el servicio militar, y las colonizaciones lejanas, fuesen los destinos de los vagos, atendidas sus diferentes circunstancias.

El establecimiento de casas de reclusión para mendigos inhábiles, sumamente benéficos si se pudiera llevar a efecto en ocho o diez ciudades o en todas las capitales de provincia, no se conseguirá en mucho tiempo por falta de suficientes medios. Bogotá ve ya planteada una, que lo es también de refugio y beneficencia, por los esfuerzos de su cámara provincial, por la liberalidad del cuerpo legislativo, y por el empeño con que han cooperado a ello sus autoridades; pero existían abundantes elementos para empresa, que realizada ha satisfecho en todos sus pormenores a los deseos y a la expectativa de los buenos ciudadanos. Ella servirá de modelo para fundar progresivamente otras; pero mientras que las hay, debe ocurrir ocurrirse a algún arbitrio que las supla en lo posible. Si no se encontraren embarazos para crear legal y permanentemente un nuevo impuesto, que de hecho y sin sentirlo se paga en todas nuestras poblaciones, con su producto puede recogerse, alojarse, mantenerse y darse oficio en ellas a los mendigos inhábiles, dictándose en el particular las reglas convenientes".

Fuente: BENÍTEZ MORALES, Otto. Bases históricas y doctrinarias del régimen social y del subsidio familiar en Colombia. Bogotá: Caja Colom- 
biana de Subsidio Familiar (Colsubsidio), 2001. Vol. 2, p. 170.

\section{DOCUMENTO $N^{\circ} 2$}

\section{(Decreto 16 de abril de 1844 sobre traslación del establecimiento de trabajos forzados de Chagras a Panamá)}

El Senado y la Cámara de Representantes de la Nueva Granada, reunidos en el Congreso decretan:

Artículo único. El poder ejecutivo podrá trasladar de Chagras a la ciudad de Panamá o a alguna de las islas del pacífico adyacentes a las de las provincias del istmo, el establecimiento de trabajos forzados que existe en el primero de estos lugares.

Bogotá, 11 de abril de 1844.

Pedro Alcántara Herrán.

\section{DOCUMENTO No 3}

\section{(Decreto del presidente Pedro Alcántara Herrán sobre concierto de vagos en las casas de reclusión. 1845)}

Pedro Alcántara Herrán, presidente de la república, teniendo en consideración:

1. Que conforme a lo dispuesto en el inciso $1^{\circ}$, artículo $1^{\circ}$ de la ley 6 de abril de 1836 (1) (lleva el No. 965 de orden) y el $1^{\circ}$ de la de 14 de junio de 1842 (lleva el No. 1390 de orden) pueden ser condenados a concierto en establecimientos públicos.

2. Que las casas de reclusión en que hay establecidos talleres de trabajos meramente ordenados, son establecimientos públicos muy adecuados para dar ocupación a los vagos.

3. Que la admisión de vagos en tales establecimientos, en calidad de concertados, no debe hacerse sino cuando de ella no resulte ni a la disciplina y orden del establecimiento,

\section{Decreta:}

Art. $1^{\circ}$. Los directores de las casas de reclusión en que hay establecidos trabajos bien ordenados, y en que el producto del trabajo de los reclusos alcance a cubrir los gastos de alimentos y vestidos de los mismos reclusos, podrán admitir en clase de concertados a los vagos de uno y otro sexo que fueren condenados a concierto por los jefes de policía.

Art. $2^{\circ}$. No obstante esta autorización, los directores de las casas de reclusión no podrán admitir en clase de concertados individuos inútiles para el trabajo, establecido en la casa, ni personas que no puedan sujetar en ellas.

Art. $3^{\circ}$. Los jefes de policía no podrán compeler a los directores de las casas de reclusión a recibir como concertados en ellas a los individuos que por vagancia o condenados a concierto en los casos siguientes:

1. Cuando el producto neto del trabajo de los reclusos no cubra los gastos de alimentos, vestido y asistencia médica de los mismos reclusos.

2. Cuando el individuo condenado a concierto sea inútil para los trabajos establecidos en la casa de reclusión.

3. Cuando el vago, fuere persona de tales circunstancias que no pueda ser fácilmente sujetada en el establecimiento.

4. Cuando el condenado a concierto parezca enfermedad contagiosa.

Art. $4^{\circ}$. Para que la admisión de los vagos, concertados en servicio en los establecimientos de reclusión tenga lugar, con la conveniente reclusión de los reclusos condenados por su sentencia en los tribunales, los respectivos directores llevarán libros separados de las condenas, entradas y salidas de vagos, pero por el mismo orden y secuela señalados en el artículo 27 , referente al $1^{\circ}$ del decreto ejecutivo del 17 de abril de 1838 reglamentario de los establecimientos de castigo.

Art. $5^{\circ}$. Los vagos admitidos como concertados al servicio de las casas de reclusión serán racionados, vestidos y asistidos en el establecimiento de mismo modo que lo son los reclusos; de manera que por el presente decreto nada se varía ni se altera en cuanto a la contabilidad y administración de los fondos de la casa de reclusión. 
Art. $6^{\circ}$. Los vagos serán ocupados en los mismos trabajos y quehaceres de los reclusos, y seguirán en todo el régimen de vida señalado para aquellos en las disposiciones que arreglan estos establecimientos. En conciencia, llevarán vestido de la misma forma, tomarán las mismas comidas, asistirán a las instrucciones y explicaciones del párroco y estarán bajo la inmediata inspección del respectivo capataz, según su sexo.

Art. $7^{\circ}$. El producto del trabajo de los vagos será distribuido del miso modo que para el de los reclusos, está ordenado en el art. 55 del decreto reglamentario de los establecimientos de castigo.

Art. $8^{\circ}$. Para la conducción y persecución de vagos prófugos y para ponerlos en libertad cuando hayan comido sus comidas, se observará en todo lo dispuesto en el citado decreto reglamentario para los reclusos que se hallan en iguales casos.

Bogotá, febrero 28 de 1845.

Pedro Alcántara Herrán.

\section{DOCUMENTO No 4}

\section{(Decreto del presidente Pedro Alcántara Herrán sobre concierto de vagos con destino a trabajar en el camino del Quindío)}

Pedro Alcántara Herrán, presidente de la Nueva Granada, considerando:

$1^{\circ}$. Que el artículo 10 y su parágrafo único de la ley 6 de abril de 1833 (lleva el número 965 de orden, los vagos pueden ser concertados para servir en establecimientos públicos y destinados a formar nuevas poblaciones, y por el artículo $3^{\circ}$ de la Ley 14 de junio de 1842 , puede igualmente obligárseles a trabajar en concierto.

$2^{\circ}$. Que en la empresa de construcción del camino del Quindío y formación de las poblaciones que en él deben establecerse, se presentan facilidades para dar ocupación los vagos con provecho de la empresa y utilidad de estos, que a la vez tienden a asegu- rarle su subsistencia durante el concierto prenderán a trabajar y adquirir el hábito de hacerlo,

Decreta:

Art. $1^{\circ}$. Autorízase al director del camino del Quindío para que pueda recibir en concierto vagos con destino a trabajar en el camino que en las obras y en establecimientos que en él deben hacerse.

Art. $2^{\circ}$. Se dará a los concertados ración y vestidos y se les asistirán cuando enfermen. Estos gastos se harán del fondo destinado por la ley para la construcción del camino del Quindío.

Art. $3^{\circ}$. Al recibir un vago en concierto, se pondrán por escrito las condiciones y el tiempo que éste debe durar. Una de las condiciones será que el vago debe trabajar diariamente en las ocupaciones para que el director lo juzgue más a propósito. En el mismo documento se expresarán los medios coercitivos de que podrá usarse para obligar al vago a trabajar y mantenerlo sujeto. Todo con arreglo a los artículos 3 y 4 de la ley 14 de junio de 1842 .

Art. $4^{\circ}$. También será una de las condiciones del concierto, que el vago pueda establecerse en las nuevas poblaciones, y si se mantiene allí una labranza que le produzca lo bastante para su sostenimiento, se le rebajarán las demás condiciones.

Art. $5^{\circ}$. Los gobernadores de Mariquita y Cauca expedirán los reglamentos y órdenes necesarios para arreglar el servicio de los vagos, que conforme a este decreto sean concertados para trabajar en la parte del camino del Quindío que corresponde respectivamente a aquellas provincias.

Art. $6^{\circ}$. Al hacer los contratos para suministrar los vestidos a los presidiarios, se harán también para los concertados, con las mismas formalidades; pero los vestidos de estos últimos no serán de los colores como los de aquellos.

Art. $7^{\circ}$. La ración para los vagos será igual a la que se suministra hoy a los presidiarios y la provisión se hará en los mismos términos. 
Art. $8^{\circ}$. Se abrirá cuenta de los gastos que se hagan en raciones y vestidos de concertados, para que este gasto se deduzca de la partida respectiva, designada en el artículo $2^{\circ}$ y no se confundirán en una sola mesa estos gastos y los que se hagan en los presidiarios que tienen fondo especial señalados por la ley. Los empleados que estarán encargados de llevar la cuenta de los gastos que se hagan en el camino del Quindío, abrirán en el libro respectivo la de ración y vestidos de los concertados.

Art. $9^{\circ}$. Los gobernadores del Cauca y Mariquita dictarán órdenes convenientes para que sean concertados los vagos que haya en la respectiva provincia conforme las disposiciones que quedan establecidas.

Dado en Bogotá, 31 de marzo de 1845. Pedro Alcántara Herrán.

\section{DOCUMENTO $N^{\circ} 5$}

(Diligencias en relación con el juicio seguido contra Evangelina Buitrago y Agustina Riaño, por vagancia)

A.G.N.

SECCIÓN: ARCHIVO ANEXO II

FONDO: MINISTERIO DE GUERRA

SERIE: ASUNTOS JUDICIALES: PROCESOS

CAJA: 2

\section{CARPETA: 4}

AÑO: 1907

FOLIOS: 1-11

Diligencias en relación con el juicio seguido contra Evangelina Buitrago y Agustina Riaño, por vagancia.

[Fol. 2r]

Ministerio de Guerra
Sección $1^{a}$

Bogotá, 26 de octubre de 1907

Señor General

Jefe de Estado Mayor General del Ejército.

E.L.C.

En el Panóptico de esta ciudad quedan a disposición de Usted, para que sean remitidas en primera ocasión a la Colonia Militar y Penal del Meta, Evangelina Buitrago y Agustina Riaño, condenadas a sufrir en dicha colonia la pena de confinamiento como vagas por dos y un años, respectivamente, como resoluciones que en dos hojas útiles acompaño á la presente.

De Usted atento servidor

Manuel M. Sanclemente.

[Fol. 3r]

El Secretario de la $1^{\text {a }}$ Mesa del Estado Mayor General del Ejército, en cumplimiento de lo ordenado por el Señor General Jefe del expresado, expide a continuación copia de las resoluciones de $1^{\text {a }}$ y $2^{\text {a }}$ instancia, dictadas en el juicio que se siguió contra Evangelina Buitrago y Agustina Riaño, por el delito de vagancia.

Resolución de $1^{\text {a Instancia }}$

República de Colombia

Policía Nacional

Comisaría Judicial

Bogotá, octubre diez y seis de mil novecientos siete.

Se ha levantado esta información con el fin de establecer la conducta de Evangelina Buitrago y Agustina Riaño. Del informe dado por el Secretario de la Sección de la Policía, aparece que la Buitrago ha sido denunciada tres veces por hurto desde mil no- 
vecientos cuatro hasta agosto del corriente año; y la Riaño o Rivera, dos veces en el año en curso.

Del informe rendido por el Secretario de la Inspección de Permanencia, aparece que la Buitrago ha sido relacionada desde mil novecientos cuatro hasta julio del año en curso, por hurto, amenazas, escándalo [Fol. 3v] y vagancia ocho veces. Respecto de la Riaño, no aparece que haya sido relacionada allí.

La Buitrago en su indagatoria confiesa que hace como dos años que no está sirviendo en ninguna parte; que ha estado en el Panóptico sufriendo pena por dos años, por hurto; y que no tiene con quién comprobar que sea mujer honrada y trabajadora.

La Riaño confiesa que ha sido llevada unas tres veces a la Policía, por sospecha de hurto; que vive con un hombre llamado Juan Bautista Cruz; y que hace como un año que no ha servido en ninguna casa, pero que ha ido a lavar donde algunas familias conocidas.

Como se ve, ambas sindicadas están en el caso del artículo $6^{\circ}$ del Decreto $N^{\circ} 928$ del año en curso, pero la culpabilidad de ambas no es igual, pues, en la Buitrago se ve la mujer completamente desmoralizada y avezada a los malos hábitos; y en la Riaño se nota apenas la falta de moralidad pero no ensenegamiento (sic) completo en el vicio [Fol. 4r] Por consiguiente, la pena que debe sufrir una y otra debe ser diferente.

Por tanto se resuelve:

Condénase a Evangelina Buitrago a la pena de un año de confinamiento; y a Agustina Riaño a la de tres meses de confinamiento.

Esta pena la sufrirán en la Colonia Penal del Meta.

Notifíquese, cópiese y consúltese.

Antonio Escalón P.

Antonio J. Posse. Secretario

Resolución de $2^{\mathrm{a}}$ instancia
Distrito Capital

\section{Gobernación}

Sección $1^{a}$

Gobierno y Justicia

Bogotá, octubre diez y nueve de mil novecientos siete

Es materia de consulta la Resolución dictada el diez y seis de los corrientes por el Señor Comisario Judicial de la Policía Nacional, por la cual se condena a Evangelina Buitrago y a Agustina Riaño, por vagancia, a sufrir la primera, la pena de un año de confinamiento en la Colonia Penal del Meta, y la segunda tres meses de la misma pena.

Para resolver la consulta, la Gobernación, considerando que los hechos imputa [Fol. 4v] dos a las sentenciadas, constitutivos del delito de vagancia, resultan comprobados con los informes del Secretario de la Sección de Justicia de la Policía y del de la Inspección de Permanencia, que corren a folios 2 y $3 \mathrm{v}$, y además, con las confesiones francas de ambas procesadas (fojas $4,5,6 v$ y 7 ), sin que ninguna de las dos hubiera intentado siquiera comprobar su buena conducta. Es pues el caso de condenarlas, al tenor del artículo $6^{\circ}$ del Decreto $N^{\circ} .928$ de tres de agosto último; pero se observa que las penas impuestas no están de acuerdo con lo dispuesto en el artículo 10 del citado Decreto, ni con las múltiples y graves fallas cometidas por la Buitrago. En efecto, respecto de la Riaño, debe observarse que el expresado artículo 10 impone la pena de confinamiento de seis meses a dos años, y en la Resolución consultada se les señala la de tres meses que es la mitad del minimun señalado allí. En cuanto a la Buitrago se ve, como se dijo ya que sus faltas son muchas y muy graves, y como lo dice la Comisaría Judicial, "se ve en ella la mujer completamente desmoralizada y avezada en los malos hábitos", necesitando, por lo mismo, mayor tiempo de aislamiento para conseguir que cambie esas costumbres.

Por estas razones, la Gobernación reforma la Resolución consultada en el sentido de que la pena de 
confinamiento que deben sufrir en la Colonia Penal del Meta Evangelina Buitrago y Agustina Riaño, es la de dos años, respectivamente.

Devuélvanse estas diligencias a la Comisaría de su origen, para los efectos del artículo 11 del Decreto ya citado.

Álvaro Uribe

Jesús M. Henao

Es fiel Copia de su original a que me remito.

[Fol. 5v]

Bogotá, treinta de octubre de mil novecientos siete.

\section{El Secretario}

Copia

\section{Arturo Dousdebés}

El infrascrito Secretario de la Comisaría Judicial

Certifica:

Que en las diligencias sumarias seguidas contra Evangelina Buitrago y Agustina Riaño, o Rivera, aparece que estas mujeres fueron detenidas el once (11) de septiembre de mil novecientos siete, por orden del Señor Alcalde $1^{\circ}$ del Distrito Capital y puestas en esa misma fecha a disposición del Señor Jefe de la Sección de Justicia. Antonio J. Posse, secretario.

Es copia conforme

Bogotá, septiembre 28 de 1908

El Coronel encargado

Milcíades Lozano

A la colona Evangelina Buitrago se le hizo venir de la Colonia Penal del Meta y se remitió a la del Magdalena, al Señor Director de ésta, con oficio №. 460, hoy 25 de septiembre de 1908 .
Firma: Lozano

Se ordenó al Director de la Colonia del Meta, en telegrama No 305, la libertad de Agustina Riaño, hoy 28 de septiembre de 1908, por haber cumplido la pena.

Firma: Lozano.

[Fol. 6r]

A Usía el Señor Gobernador del Distrito Capital

Yo, Evangelina Buitrago, mayor de edad y actualmente presa en la Colonia Militar, Agrícola y Penal de Santa Marta, a Usía con el acatamiento y respeto debido, expongo: Fui condenada por Resolución dictada por el Señor Comisario Judicial de la Policía Nacional, en primera instancia, a un año de confinamiento en una Colonia y fue en segunda instancia a Gobernación, habiéndome impuesto la pena de dos años. El objeto primordial de mi memorial es imponer a Usía la causa de la falta que cometí. Por mi escasa inteligencia y criterio, contesté groseramente a la autoridad que me tomó investigación, no pudiendo contestar los cargos de una manera adecuada que se me seguían por vagancia. Antes de hacerme la Audiencia el Señor Comisario, estuve siete meses presa en el "Buen Pastor" y tres en el Panóptico de esa Ciudad, tiempo que no se me computó como prisión preventiva. Como Usía puede ver en la copia que tengo el honor de adjuntarle, el 11 de septiembre de 1907 se me empezó a contar la pena de manera que al 11 del mes en curso llevo pagados 17 meses de prisión cumplidos en la Colonia del Meta y en ésta prestando mis servicios como cocinera. Debido a esto me he enfermado de gravedad, he implorado misericordia de Usía, pido me conceda rebaja de la tercera parte de la pena a que fui condenada, y como ya he pagado más de las dos terceras partes, se me dé mi liberad, acogiéndome al artículo 114 del Código Penal.

[Fol. 6v]

Los sufrimientos me han reformado completamente y ya regenerada volveré á servir de apoyo a mi anciana madre ayudándola en sus trabajos de vivandera. Todos los certificados relativos a la buena conducta que he observado los remití al Ministerio de Guerra. 
Sólo acompaño uno de la Dirección de ésta Colonia en el que consta mi conducta. Si Usía necesita los otros certificados los puede pedir al Ministerio o yo me haré expedir otros si así lo exigieren.

Suplicando a Usía de justicia mi libertad, espero una favorable resolución.

Fundación, 18 de febrero de 1909

A ruego de Evangelina Buitrago, Santiago Valenzuela.

El 3 de marzo de 1909, se pasa la petición al Señor Comisario Judicial de la Policía Nacional para que resuelva lo pertinente.

\section{[Fol. 9r]}

El infrascrito Secretario de la Colonia Agrícola y Penal de Santa Marta

Certifica:

Que la conducta observada por la Colona Evangelina Buitrago, durante toda su permanencia en esta Colonia, ha sido muy buena, prestando sus servicios como cocinera cumpliendo bien tal encargo. Lo expuesto es la verdad.

Fundación, febrero 10 de 1909

Firma: Tomás Pérez

[Fol. 10r]

[Sello del Ministerio de Guerra, Comisaría Judicial]

Bogotá, marzo seis de mil novecientos nueve

Evangelina Buitrago confinada en la Colonia Penal y Agrícola de Santa Marta solicita que se le rebaje la tercera parte de la pena de dos años a que fue condenada por mala conducta.

A su solicitud acompaña las copias respectivas de las resoluciones porque fue condenada, y un certificado del Jefe de la Colonia en el que consta que ha observado muy buena conducta y que ha prestado sus servicios como cocinera. La peticionaria alega como circunstancia bien especial para que se le conceda tal gracia la de haberse enfermado en esa Colonia.

Como las faltas, porque fue castigada la Buitrago, no son de aquellas que entrañan mayor gravedad, porque no aparece que haya cometido ninguno de los delitos que son mirados como más graves por la legislación; y como, por otra parte, puede decirse del informe del Señor Secretario que esta mujer se haya corregida y dispuesta a observar en adelante buena conducta, la Comisaría

Resuelve:

Concédese a Evangelina Buitrago, la rebaja de la tercera parte de la pena que se le impuso por resoluciones de esta Comisaría y de la Gobernación, de fechas 17 y 19 de octubre de 1907.

Cópiese y consúltese.

Firma: A. Escallón.

El Ministerio confirma la resolución de la rebaja de pena y ordena que se deje en libertad, con fecha de mazo 10 de 1909.

Se envía telegrama ordenando la libertad de la Buitrago.

\section{DOCUMENTO No 6}

(Diligencias contra Abraham Cuervo, por vago)

A.G.N.

SECCIÓN: ARCHIVO ANEXO II

FONDO: MINISTERIO DE GUERRA

SERIE: ASUNTOS JUDICIALES. PROCESOS

CAJA: 3

CARPETA: 1

AÑO: 1905 
FOLIOS: 7-10

Diligencias contra Abraham Cuervo, por vago

[Fol. 8r]

Prefectura de la Provincia

Bogotá junio 5 de 1905

Señor General Comandante en Jefe del Ejército

El Señor Alcalde de Tocancipá me ha remitido a Abraham Cuervo, como individuo de mala conducta, vago y ratero, para que sea enviado a las Colonias Penales, pero, en concepto de la Prefectura, es mejor que Cuervo ingrese al ejército y preste allí su servicio, como zapador.

Hay declaraciones en las cuales consta que dicho sujeto es tahúr y que es además una amenaza para la población.

En consecuencia, tengo el honor de ponerlo a sus órdenes para que disponga lo conveniente

Dios Guarde a Usted

Firma: Juan A. Gerlessi

[Fol. 8v]

Comandancia en Jefe

Bogotá, Junio 5 de 1905

Acúsese recibo y pase al Estado Mayor General, para que se examine el individuo que se remite y se informe, a fin de dar cumplimiento a lo dispuesto en la Resolución del Ministerio de Guerra № 40, del año en curso.

Por el Comandante en Jefe

El General Jefe

Euclides de Angulo.

Junio 5 de 1905
Remítase el individuo al Principal del Ejército y pase este oficio original a los señores Médicos Oficiales para su reconocimiento. Vuelva con la constancia.

El General Jefe

Angulo.

Bogotá, junio 7 de 1905

Abraham Cuervo está en condiciones de salud cumplida, y por tanto puede dedicarse al trabajo.

Dr. P. Pizarro

[Fol. 9r]

Abraham Cuervo fue incorporado en el Batallón Calibío el 15 de junio último, según informe del Jefe del Cuerpo.

\section{DOCUMENTO No 7}

(Diligencias contra Gamaliel Rodríguez, por vago y pernicioso)

A.G.N.

SECCIÓN: ARCHIVO ANEXO II

FONDO: MINISTERIO DE GUERRA

SERIE: ASUNTOS JUDICIALES: PROCESOS

CAJA: 3

CARPETA: 1

AÑO: 1905

FOLIOS: 116-123

Diligencias contra Gamaliel Rodríguez, por vago y pernicioso

[Fol. 117v]

En el Distrito Capital de Bogotá y en el Despacho del Estado Mayor General del Ejército, hoy catorce de julio 
de mil novecientos cinco, se presentó el Señor Marco A. Piñeros, mayor de [Fol. 118r] edad y vecino de esta ciudad, con el objeto de constituirse ante el Gobierno como fiador del Señor Gamaliel Rodríguez, de que se presentará mañana por la mañana en el Despacho del Señor Gobernador del Departamento de Cundinamarca, a quien se remitieron todas las diligencias conducentes a la reclamación del Señor Rodríguez, lo mismo que las enviadas por el Señor Alcalde de Nocaima como justificación a su providencia de remitir a este Despacho al fiador, Señor Rodríguez como vago, afín de que dicha superioridad resuelva lo conveniente, por ser de su competencia, según lo dispuesto en la Resolución Nº 40, de 6 de mayo último, del Ministerio de Guerra. El valor de la fianza es de cincuenta pesos (\$50) oro, más los gastos de la aprehensión del fiado hasta obtener su captura en caso de que no cumpla con el deber de presentarse ante la autoridad antes dicha. En constancia, se extiende la presente diligencia que se firma por el fiador, el Señor General Jefe de Estado Mayor General del Ejército, por ante el infrascrito Secretario.

Firma: Euclides de Angulo.

[Fol. 120r]

Telegrama

Facatativá, 26 de julio de 1905

Jefe Estado Mayor General del Ejército

Hoy presentóse a este despacho, el Señor Gamaliel Rodríguez, de quien di cuenta ayer a Usted que se había ausentado de esta sin haberse resuelto nada respecto a él.

Estado Mayor General

Julio 26 de 1905

Acúsese recibo y dígase que hay repetidas quejas contra Rodríguez.

El General Jefe

Firma: Angulo
[Fol.122r]

Resoluciones dictadas por la Gobernación del Departamento de Cundinamarca

República de Colombia

\section{Departamento de Cundinamarca}

Gobernación

Facatativá, 26 de agosto de 1905

La parte final de la Circular del Excelentísimo Señor Presidente de la República, de 28 de enero último, preceptúa que los individuos revoltosos y vagos que sean causa de intranquilidad pública, deben enviarse al Gobierno para resolver respecto de ellos lo más conveniente; pero el ordinal 3 de la Resolución número 40 del 6 de mayo próximo pasado, manda que los perniciosos y vagos sanos deben destinarse a la guarnición más cercana de la cabecera de Provincia, en tanto que se redimen de sus vicios y mala conducta.

Ahora bien, examinada cuidadosamente la documentación levantada sobre los procedimientos del Señor Gamaliel Rodríguez, en el Municipio de Nocaima, aparece de las declaraciones rendidas... y del certificado expedido por el Señor Cura Párroco; de allí, que el citado Señor Rodríguez es persona perniciosa por su conducta inmoral; que es vago, puesto que no se le conoce oficio ninguno; esto es, que está comprendido en el inciso $2^{\circ}$. del artículo 490 del C. de P., y que es revoltoso, por que es amigo de motines [Fol. 122v] Estos testimonios hacen plena prueba de los hechos aseverados al tenor del artículo 1675 del C. J. y la certificación del Párroco lo es también, según el 1667 referente al ordinal $1^{\circ}$ del 678 de allí. De manera que el Señor Gamaliel Rodríguez debe imponérsele la pena señalada en la Resolución número 40 referida. Más, como toda pena admite atenuación según el articulo 119 de C.P. concordante con el 1576 del C.J. y la Gobernación observa que en el proceso figuran causales bastantes para ello, no hay duda que procede tal atenuación. Con efecto, las manifestaciones de los Señores [Hace relación de los nombres de los otros 
testigos]... al respeto de que el Señor Gamaliel Rodríguez es persona honrada, obediente a la ley, amigo del progreso, de exquisito tacto social, aún con sus mismos enemigos políticos, cumplidor asiduo de los deberes sociales, y partidario y defensor del actual Gobierno, imponen la justa atenuación. Y como de aquellas diligencias aparece también claramente el desagrado de muchos vecinos de Nocaima por la presencia del Señor Rodríguez allí, y el peligro de su vida, la Gobernación, teniendo en cuenta que Salus populi supremae lex, esto otorga la dicha necesaria atenuación.

Por todo lo expuesto, la Gobernación

Resuelve:

Apercíbase al Señor Gamaliel Rodríguez, a que permanezca ausente del Municipio de Nocaima [Fol. 123r] por un lapso suficiente a aquietar los ánimos de aquel Distrito; quedando a cargo de la primera autoridad política del Departamento o de la que la reemplace en sus funciones el cuidado de poner en conocimiento de Rodríguez el tiempo en que pueda regresar al mencionado Municipio, previo informe de las autoridades y de las personas de mayor escala social de allí.

Cópiese, publíquese y notifíquese

Belisario Ayala. El Secretario General. Adriano Tribin.

\section{REFERENCIAS BIBLIOGRÁFICAS}

ÁLVAREZ URÍA, Fernando. Medicina mental y orden social en la España del siglo XIX. Barcelona: Tusquets, 1983.

BALCÁZAR PARDO, Marino. Disposiciones sobre indígenas, adjudicación de baldíos y represión de estados antisociales (vagos, maleantes y rateros). Primera edición arreglada y dirigida por Marino Balcázar Pardo, jefe de la Sección de Justicia y Minas del departamento del Cauca, 1954.

BRADING. D. A. "La España de los borbones y su imperio americano" en Betthell Leslie (editor). Historia de América Latina, tomo 2. Barcelona: Editorial Crítica - Cambridge University Press, 1990.
CASTRO CARVAJAL, Beatriz. Caridad y beneficencia, el tratamiento de la pobreza en Colombia. Bogotá: Universidad Externado de Colombia.

CASTRO, Beatriz. Caridad y beneficencia en Cali, 1848-1898. Boletín Cultural y Bibliográfico. Vol. 27, $\mathrm{N}^{\circ} 22,1990$.

CODIFICACIÓN NACIONAL. Año de 1844. Compilación de normas 1810-1910.

FOUCAULT, Michel. Microfísica del poder. Del archivo al diagrama, Foucault, un nuevo cartógrafo. Madrid: Ediciones La Piqueta, 1983.

Michel. Saber y Verdad, una genealogía del poder. Madrid: Ediciones La Piqueta, 1991.

Las palabras y las cosas, Barcelona: Planeta Agostini, 1984.

La verdad y las formas jurídicas. Barcelona: Editorial Gedisa, 2000.

Poder, Derecho, Verdad. En: Poder vs. Democracia. Bogotá: Fundación para la Investigación y la Cultura (FICA) 2004.

Seguridad, territorio, población. Curso en el Collège de France (1977-1978). Buenos Aires: Fondo de Cultura Económica, 2006.

Verdad y poder. Diálogo con M. Fontana, en: Un diálogo sobre el poder y otras conversaciones. Selección e introducción de Miguel Morey. Madrid, Alianza Editorial, 2004.

Nietzsche, la genealogía, la historia. Valencia, España: Pretextos. 2004.

No al sexo rey. Entrevista por Bernard HenryLevy, en Un diálogo sobre el poder y otras conversaciones. Selección e introducción de Miguel Morey. Madrid: Alianza Editorial, 2004.

Poder, Derecho, verdad, en Poder vs. Democracia. FICA. Bogotá: Fundación para la Investigación y la Cultura. Bogotá, 2004. 
Historia de la sexualidad. México: Siglo XXI Editores, 1986.

FROISLAND, Hayley. Caridad, asistencia pública y moralización: El mantenimiento de un orden social paternalista y jerárquico en Colombia, 18501940. Publicado en: Memoria y Sociedad. Revista del Departamento de Historia y Geografía. Bogotá: Universidad Javeriana, Vol. 2, No. 4, noviembre de 1977.

GEOCRÍTICA. Cátedra de Geografía Humana, Revista de la Facultad de Geografía e Historia, Universidad de Barcelona, No 23, Poder y Espacio. Septiembre de 1979.

IGGERS, George, G. La ciencia histórica en el siglo XIX. Las tendencias actuales: una visión panorámica y crítica del debate internacional. Barcelona: Idea books, S.A., 1998.

JURADO JURADO, Juan Carlos. Vagos, pobres y mendigos. Contribución a la historia social colombiana 1750-1850 Medellín: Editorial La Carreta, 2004.

MEMORIAS SEMINARIO MICHEL FOUCAULT (19842004). Autores varios. Víctor Florián (Compilador) Bogotá: Universidad Libre, Uniediciones y Embajada de Francia, 2005.

NOGUERA, Carlos Ernesto. Medicina y política. Discurso médico y prácticas higiénicas durante la primera mitad del siglo XX en Colombia. Medellín: Fondo Editorial Universidad EAFIT, 2003.

RAMOS PEÑUELA, Aristides. Los caminos al río Magdalena. La frontera del Carare y el Opón 1760-1860. Bogotá: Instituto Colombiano de Cultura Hispánica, 2000.

RAMÍREZ, María Himelda. La infancia abandonada en Santa Fe colonial: entre la caridad privada y la tutela estatal (1641-1810) en: Revista de trabajo Social, 2, Departamento de trabajo social. Facultad de ciencias Humanas. Universidad Nacional de Colombia. Bogotá, Noviembre de 2000.

De la caridad barroca a la caridad ilustrada. Mujeres, género y pobreza en la sociedad de Santa
Fe de Bogotá, siglos XVII y XVIII. Bogotá: Universidad Nacional de Colombia, 2006.

ROBLEDO GÓMEZ, Ángela María y RODRÍGUEZ SANTANA, Patricia. Emergencia del sujeto excluido. Aproximación genealógica a la no-ciudad en Bogotá. Bogotá: Editorial Pontificia Universidad Javeriana, 2008.

RODRÍGUEZ ÁVILA, Sandra. De la caridad cristiana a la caridad ilustrada: Educación y policía en el siglo XVIII", en Folios, Revista de la Facultad de Humanidades de la Universidad Pedagógica Nacional, 19, primer semestre de 2004.

SÁENZ OBREGÓN, Javier; SALDARRIAGA, Óscar y OSPINA, Armando. Mirar la infancia: Pedagogía, moral y modernidad en Colombia, 1903-1946. Colciencias, Ediciones Foro Nacional por Colombia, Ediciones Uniandes y Universidad de Antioquia, 1997.

VARGAS, Julián y VERA, Guillermo. Formas asistenciales y de beneficencia en Santa Fe: hospitales, expósitos y hospicios", en Julián Vargas Lesmes. La sociedad de Santafé colonial, CINEP, Bogotá, 1990.

\section{Archivo General de la Nación (A.G.N.)}

A.G.N. Sección: Colonia. Fondo Real Audiencia Cundinamarca, T. 11.

A.G.N. Sección: Archivo Anexo II. Fondo: Ministerio de Guerra. Serie: Asuntos Judiciales, Procesos. Caja 3. Carpeta 3. Año 1903.

A.G.N. Sección: Archivo Anexo II. Fondo: Ministerio de Guerra. Serie: Asuntos Judiciales, Procesos. Caja: 3. carpeta 1. Año 1905.

A.G.N. Sección: Archivo Anexo II. Fondo: Ministerio de Guerra. Serie: Asuntos Judiciales, Procesos. Caja 2. Carpeta 4. Año 1907.

A.G.N., Sección: Archivo anexo II. Fondo: Ministerio de Guerra. Serie: Asuntos Judiciales, Procesos. Caja 1, Carpeta 1. Año: 1895-1908.

A.G.N. Sección: República. Fondo: Gobernaciones varias. Tomo: 117 
A.G.N. Sección: República. Fondo: Gobernaciones varias. Tomo: 118 .

A.G.N. Sección: República. Fondo: Gobernaciones varias. Tomo: 103.
A.G.N. Sección: Colonia. Fondo: Real Audiencia - Cundinamarca. Curas y obispos, Tomo 48. № 105, años 1776-1778.

A.G.N. Sección: República. Fondo: Gobernaciones Varias. Tomo: 191. Caja: 1. Carpeta: 2. 